\title{
Water Wave Propagation Caused by Underwater Blasting in a 3D Numerical Wave Tank
}

\author{
Woo-Dong Lee $\circledast^{*}$, Yeon-Myeong Jeong $\bigoplus^{* *}$, Kyu-Nam Choi ${ }^{* * *}$ and Dong-Soo Hur@* \\ "Department of Ocean Civil Engineering, Institute of Marine Industry, Gyeongsang National University, Tongyeong, Korea \\ "Institute of Marine Industry, Gyeongsang National University, Tongyeong, Korea \\ ${ }^{*}$ Daewoo Engineering \& Construction Co., Ltd., Seoul, Korea
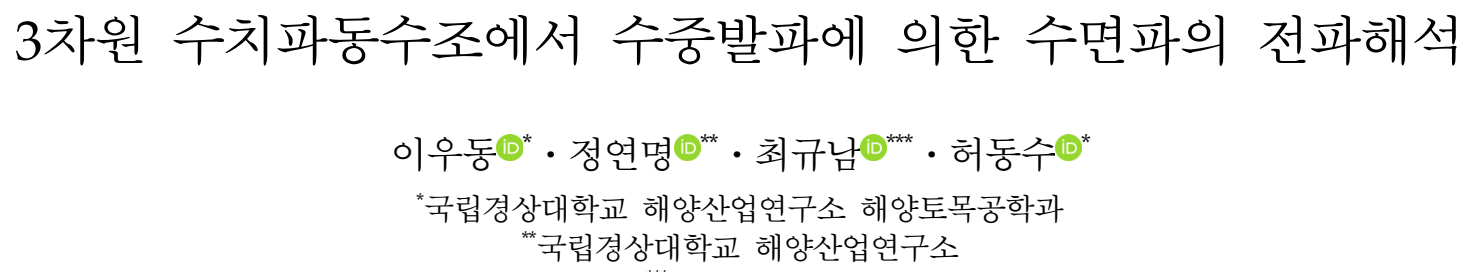

KEY WORDS: Underwater blasting 수중발파, Shock wave 충격파, Water wave 수면파, Wave propagation 파랑전파, 3-D numerical wave tank 3차원 수치파동수조

\begin{abstract}
When underwater blasting is conducted, both shock waves and water waves have an effect on adjacent coastal areas. In this study, an empirical formula for estimating the details of water waves caused by underwater blasting was applied to a non-reflected wave generation system, and a $3 D$ numerical wave tank (NWT) was improved to reproduce the generation and propagation of such water waves. The maximum elevations of the propagated water waves were comparatively analyzed to determine the validity and effectiveness of the NWT. Good agreement was demonstrated between the empirical and simulation results. The generation and propagation of water waves were also simulated under each underwater blasting scenario for the removal of the Todo islet at the Busan Newport International Terminal (PNIT). It was determined that the water waves generated by the underwater blasting scenario examined in this study did not have a significant impact on the PNIT. In addition, multiple-charge blasting caused higher wave heights than single-charge blasting. As the amount of firing charge increased, the wave height also increased. Finally, larger water waves were generated during the later blasting conducted at a deeper depth as compared with an earlier blasting conducted at a relatively shallow depth.
\end{abstract}

\section{1. 서 론}

수중발파는 일반적으로 부피가 큰 수중의 구조물/장애물을 철거하는 과정에 필요한 공정이다. 해양개발이 지속적으로 진 행됨에 따라 수중발파 또한 증가하는 추세이다. 그리고 해안 및 항만 공사에서는 대규모의 수중발파가 수반되는 경우가 많다. 대표적 예로서 부산신항만에서는 선박의 입 - 출항에 걸림돌이 되어온 토도를 제거하기 위해 수중발파를 동반한 공사가 진행 되고 있다. 해양수산부는 2018년부터 2020년까지 국비 3,437억 원을 투입하여 부산신항만의 선반 운항의 안전과 항만 운용의
효율성을 높이기 위해 토도 제거를 추진하며, 수심 $-17 \mathrm{~m}$ 를 확보 할 예정이다.

Fig. 1처럼 수중폭파는 공기 중 폭발과 같이 순간적으로 발생 하며, 고압의 충격파가 수중에서 빠른 속도로 전파된다. 수중에 서는 공기보다 압력전파속도가 빠르고, 발생한 가스 또는 에너 지가 소실 전에 물에 의해 기포 형태로 갇히게 된다(Choi et al. 2017). 충격파는 기포 크기가 최소일 때 발생하고, 이 기포는 외 부 압력과 중력의 영향으로 팽창과 수축을 반복하며, 수면으로 상승하게 된다(Hunter and Geers, 2002; Klaseboer et al., 2005; Hamashima et al., 2010). 이러한 일련의 과정이 수중폭파지점을

Received 9 January 2019, revised 23 July 2019, accepted 12 August 2019

Corresponding author Dong-Soo Hur: +82-55-772-9122, dshur@gnu.ac.kr ORCID: http://orcid.org/0000-0003-4627-7593

It is noted that this paper is revised edition based on proceedings of Fall Conference of KSOE 2018 in Incheon.

(c) 2019, The Korean Society of Ocean Engineers

This is an open access article distributed under the terms of the creative commons attribution non-commercial license (http://creativecommons.org/licenses/by-nc/3.0) which permits unrestricted non-commercial use, distribution, and reproduction in any medium, provided the original work is properly cited. 


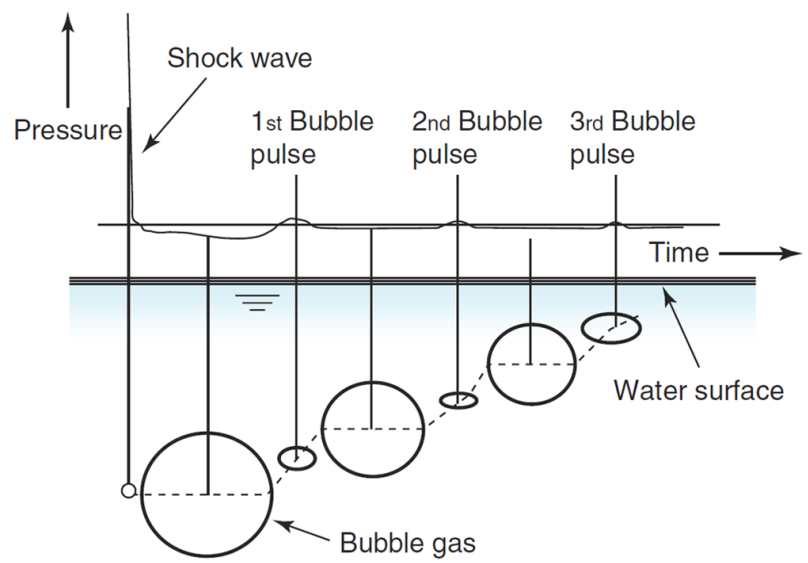

Fig. 1 Schematic illustration of underwater explosion phenomenon (Hamashima et al., 2010)

기점으로 한 수면파동을 발생시키고, 주변 해역까지 영향을 미 치게 된다. 그러므로 가동 중인 부산신항만에서 수행하는 토도 제거를 위한 수중발파의 수면파동이 컨테이너 터미널에 미치는 영향을 면밀하게 검토할 필요가 있다.

수중폭파에 관한 연구들은 대부분 충격파의 물리적 특성을 분석(Cole, 1948; Costanzo, 2011)에 중점을 두고, 충격파가 주변 구조물(Zhang et al., 2017; Saadatfar and Zahmatkesh, 2018), 선박 (Warren, 1996; Ming et al., 2016), 생태계(Keevin and Hempen, 1997; Govoni et al., 2008)에 미치는 영향을 분석 또는 모니터링 (Carlson et al., 2011)을 수행하였다. 이에 반해 수면파의 발생 및 전파에 관한 연구들은 아직까지 미진한 실정이다. 국내에서 는 수중발파 사례분석에 관한 연구(Jeung et al., 2004; An et al., 2007; Kim and Kim, 2018)가 주로 수행되었다. 그리고 수중발파 현장에서 측정한 자료로부터 진동추정식을 제안하였다(Park et al., 2006). 수중발파에 대한 어류 및 구조물의 영향평가(Lee et al., 2001; Choi et al., 2015)에 관한 연구도 수행되었다.

최근에서는 $\mathrm{CFD}$ (Computational fluid dynamics) 기반의 수치해 석에서 수중폭파에 의한 수면파동이 계산되기도 한다. Miller et al.(2013)은 유한 체적법의 이상류 해석으로부터 수중폭파 시에 압력강하에 의한 동공현상, 기포 상승, 수면파 생성에 관한 수 치해석을 수행하기도 하였으나, 수면파 전파과정에 관한 검토 는 수행되지 않았다. Wang et al.(2014)의 다상류 해석에서는 충격파와 공동현상에 의한 수면파동이 발생하나, 이것에 대한 논의가 이루어지지 않았다. 현실적으로 수중폭파부터 수면파 동의 발생과 전파까지 직접 모의하기에는 많은 어려움이 따른 다. 한편 Le Méhauté and Wang(1996)은 수중발파 시에 TNT (Trinitrotoluene) 장약량에 따른 최대수위, 수면파의 주기 등에 관한 경험식을 제안하였다. 이 경험식을 이용하여 수중폭발에 따른 수면파의 발생과 전파를 해석한다면, 전술한 이상류 또는 다상류 수치모델이 아닌 단상류 수치모델에서도 시뮬레이션이 가능할 것이다.

본 연구에서는 Navier-Stokes(N-S) 방정식에 기반의 단상류 수 치모델 LES-WASS-3D Ver. 2.0(Lee and Hur, 2014a)을 이용한다. 그리고 Le Méhauté and Wang(1996)의 추정식을 무반사 조파시 스템에 적용하는 방법을 제안한다. 나아가 부산신항만의 토도
제거를 위한 수중발파 시나리오별 수면파의 발생과 전파에 관 한 3차원 시뮬레이션을 수행하여 주변 컨테이너 및 다목적 터 미널에 미치는 영향을 분석한다.

\section{2. 수치모델}

본 연구에서는 수중발파에 의한 수면파의 3 차원적 전파특성 을 분석하기 위하여 LES-WASS-3D ver. 2.0(Lee and Hur, 2014a) 을 이용한다. 이 3 차원 수치파동수조는 PBM(Porous body model) 과 $\mathrm{VOF}$ (Volume of fluid)를 토대로 개량된 3-D N-S Solver의 강 비선형 모델이다. 그리고 무반사 조파시스템에 의해 파와 흐름 을 자유자재로 생성할 수 있다. 아격자 규모의 난류해석을 위해 Smagorinsky(1963)에 기초한 Germano et al.(1991)과 Lilly(1992) 의 동적 와동점성모델, 자유수면의 표면장력을 고려하기 위해 Brackbill et al.(1992)의 CSF(Continuum surface force)모델을 수치 파동수조에 각각 도입하였다.

\section{1 지배방정식}

지배방정식은 비압축성 - 점성유체에서 무반사로 파 또는 흐 름을 생성할 수 있게 조파원천이 포함된 연속방정식 (1)과 PBM 을 토대로 질량 및 에너지 보전, 투수매체에 의한 에너지 소산 을 정량적으로 계산할 수 있게 수정된 N-S 운동량 방정식 (2)로 구성된다.

$$
\begin{aligned}
& \frac{\partial\left(\gamma_{i} v_{i}\right)}{\partial x_{i}}=q^{*} \\
& \frac{\partial\left(\gamma_{v} v_{i}\right)}{\partial t}+\frac{\partial\left(\gamma_{i} v_{i} v_{j}\right)}{\partial x_{j}}=-\frac{\gamma_{v}}{\rho} \frac{\partial p}{\partial x_{i}}+\frac{\partial\left(\gamma_{i} \nu_{T} D_{i j}\right)}{\partial x_{j}}+S_{i}-Q_{i}-R_{i}-\gamma_{v} g_{i}-E_{i}
\end{aligned}
$$

여기서 $v_{i}$ 는 $x, y, z$ 방향의 유속성분, $q^{*}$ 는 소스의 유량밀도, $\gamma_{v}$ 는 체적공극률, $\gamma_{i}$ 는 $x, y, z$ 방향의 면적투과율, $t$ 는 시간, $\rho$ 는 수온과 염분을 고려한 물의 밀도, $p$ 는 압력, $\nu_{T}$ 는 수온과 염분 에 따른 물의 동점성계수 $(\nu)$ 와 동적 난류모델에서 구한 와동점 성계수 $\left(\nu_{t}\right)$ 의 합, $D_{i j}$ 는 변형률속도텐서, $S_{i}$ 는 $\mathrm{CSF}$ 모델에 의한 표면장력항, $Q_{i}$ 는 조파원천항, $R_{i}$ 는 투과매체의 유체저항항, $g_{i}$ 는 중력가속도항, $E_{i}$ 는 에너지 감쇠항을 각각 나타낸다.

$F$ 는 각 계산 격자에서 유체의 체적비를 나타내고, 비압축성 유체에 대한 가정과 $\mathrm{PBM}$ 을 적용하여 $\mathrm{VOF}$ 함수를 유체의 보존 형식으로 나타내면 다음과 같다.

$$
\gamma_{v} \frac{\partial F}{\partial t}+\gamma_{i} v_{i} \frac{\partial F}{\partial x_{i}}=F_{q}^{*}
$$

세부적인 수치해석방법에 대해서는 Hur et al.(2012)과 Lee and $\operatorname{Hur}(2014 \mathrm{a})$, Lee and Hur(2014b)를 참조하기 바란다.

\section{2 조파방법}

2.2.1 수면파형

수중폭파에 발생하는 수면파형은 크노이드파 형태를 가진다 


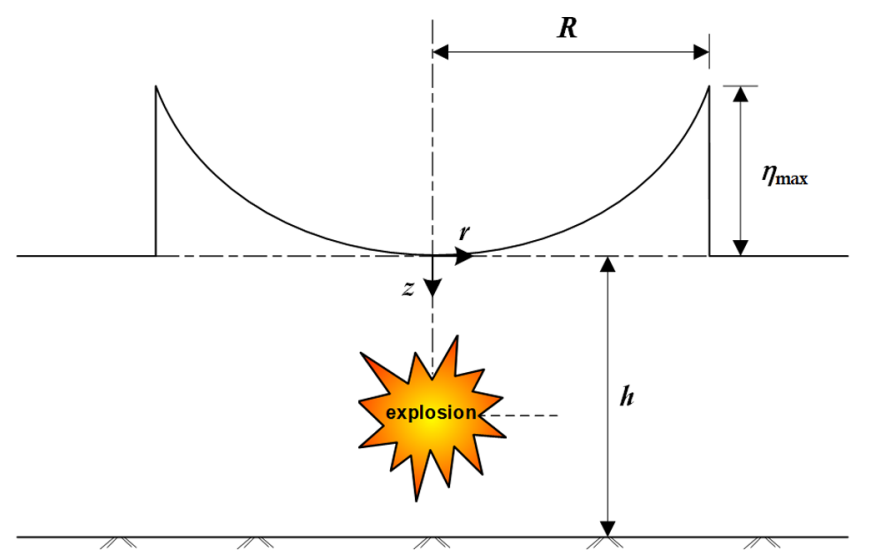

Fig. 2 Schematic illustration of initial water waveform due to underwater explosion

(Le Méhauté and Wang, 1996), 본 연구에서는 수중폭파에 의한 수면파는 단파임을 감안하여 크노이드파를 대신한 비주기성의 고립파를 적용한다. 이에 Le Méhauté and Wang(1996)는 실험을 통해 천해역에서 TNT 장약량에 따른 최대수위, 수면파의 주기 등에 관한 경험식을 이용하며, Fig. 2처럼 수중폭파 시에 생성되 는 고립파형의 수면파 제원을 식 (4)-(6)들로부터 얻을 수 있다.

$$
\begin{aligned}
& \frac{\eta_{\max } r^{\alpha}}{W^{\beta}}=C_{W} \\
& R=\left\{\begin{array}{l}
9.54 W^{0.3}: 0<\frac{z}{W^{0.3}}<0.25 \\
10.77 W^{0.3}: 0.25<\frac{z}{W^{0.3}}<7.5
\end{array}\right. \\
& T=\left\{\begin{array}{l}
1.669 W^{0.15}: 0<\frac{z}{W^{0.3}}<0.25 \\
1.773 W^{0.15}: 0.25<\frac{z}{W^{0.3}}<7.5
\end{array}\right.
\end{aligned}
$$

여기서 $\eta_{\max }$ 는 최대수위, $r$ 은 발파지점으로부터의 수평거리, $W$ 는 TNT 기준 장약량, $\alpha$ 와 $\beta$ 는 식 (7)-(8)과 같은 경험계수, $C_{W}$ 는 식 (9)과 같은 경험계수, $R$ 은 초기 수면형의 반경, $T$ 는 주기, $h$ 는 수심, $z$ 는 발파 수심을 각각 나타낸다. 여기서 단위는 $\mathrm{ft}$ 와 $\mathrm{lb}$ 이다.

$$
\begin{aligned}
& \alpha=0.83\left(\frac{h}{W^{1 / 3}}\right)^{0.07} \\
& \beta=\frac{\alpha}{3}+0.25 \\
& C_{W}=1.44\left(\frac{h}{W^{1 / 3}}\right)^{0.93}
\end{aligned}
$$

본 연구에서는 이 경험식에서 산정되는 수면파의 제원을 무 반사 조파시스템에 적용하여 수면파의 생성과 전파를 모의한다.

\subsection{2 조파방법}

양방향으로 파랑이 생성되는 방식(Brorsen and Larsen, 1987) 을 개량하여 수치파동수조의 4 방향 $(x$ 의 \pm 방향, $y$ 의 \pm 방향)으 로 수면파를 전파될 수 있게 조파원천을 개량하였으며, 식 (10) 과 같이 4 배의 조파강도 $(q)$ 를 가진다. 그리고 수치파동수조 내 의 장애물 또는 경계로부터 발생하는 반사파의 영향을 최소화 하기 위하여 Ohyama and Nadaoka(1991)가 제안한 강도조절계수 ( $\zeta$ )을 적용하여 안정적으로 수면파를 생성한다.

$$
q=4 \zeta V_{0}
$$

여기서 $V_{0}$ 는 수면파의 수평 유속성분, $\zeta$ 는 강도조절계수 $\left(\left(\eta_{0}+h\right) /\right.$ $\left(\eta_{s}+h\right), \eta_{0}$ 는 이론적 수면 변위, $\eta_{s}$ 는 실제 수면 변위)이다.

엇갈림 격자체계를 채택한 수치모델에서는 격자 크기에 따른 $q$ 의 영향을 배제할 필요가 있다. 본 연구에서는 식 (11)처럼 격 자 크기의 영향이 없는 유량밀도 $\left(q^{*}\right)$ 를 지배방정식에 대입한다. 그리고 단일발파의 조파영역은 하나의 격자가 되지만, 다중발 파의 조파영역은 장약량과 발파공의 수에 따라 결정된다.

$$
q^{*}= \begin{cases}q(y, z, t) / \Delta x_{s}: & x=x_{s} \\ 0 & : x \neq x_{s}\end{cases}
$$

본 연구에서는 수중폭파에 의한 수면파형에 고립파 근사이론 을 적용하며, Lee et al.(2016)이 다양한 고립파형을 조파할 수 있는 제안한 방법을 이용한다. 고립파의 수면파형은 Dean and Dalrymple(1991)의 근사이론을 이용하며, 시간파형과 수립자의 수평유속은 식 (12)-(13)과 같다.

$$
\begin{aligned}
& \eta_{0}=\eta_{\max } \operatorname{sech}^{2}\left[\sqrt{\frac{3}{4} \frac{\eta_{\max }}{h^{3}}}\left(x_{s}-a\right)\right] \\
& V_{0}=\left[\lambda\left\{\epsilon+3 \epsilon^{2}\left(\frac{1}{6}-\frac{z_{h}^{2}}{2}\right)\right\}-\lambda^{2} \epsilon^{2}\left(\frac{7}{4}-\frac{9 z_{h}^{2}}{4}\right)\right]
\end{aligned}
$$

여기서 $\eta_{\max }$ 는 최대수면높이, $C$ 는 식 (14)과 같은 파속, $\lambda$ 는 수 면변위와 최대수면변위와의 비 $\left(\eta / \eta_{\max }\right), \epsilon$ 는 최대수면변위와 수 심과의 비 $\left(\eta_{\max } / h\right), z_{h}$ 는 바닥과 수립자의 연직거리와 수심과의 비이다.

$$
C=\sqrt{g h}\left(1+\frac{\eta_{\max }}{2 h}\right)
$$

\section{3 수중발파에 의한 수면파를 위한 경계조건}

대부분의 수치파동수조는 진행파의 양방향에 부가감쇠영역을 설치하고, 측면경계에 있어서 Non-slip 또는 Slip 조건을 사용한 다. 이처럼 적용할 경우, 수중발파에 의한 수면파는 4 방향으로 전파되기 때문에 측면경계에서 반사파가 발생하여 파동장 교란 이 발생하게 된다. 이것을 보완하기 위해 Hur and Lee(2011)는 수치파동수조에서 경사입사파의 조파를 위한 수조경계의 반사 


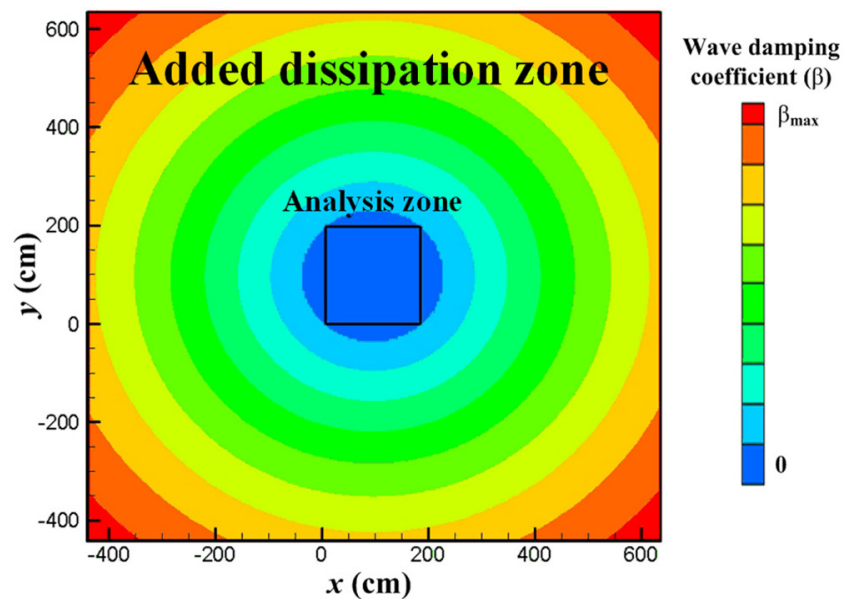

Fig. 3 Schematic illustration of added dissipation zone with wave damping coefficients in NWT

파 제어를 Fig. 3이 같은 부가감쇠영역(Added dissipation zone)과 방사형 파랑감쇠계수( $\beta$; Wave damping coefficient)를 설정하였 다. 여기서 $\beta$ 는 다음 식 (15)에 대입되어 연직유속 $(w)$ 만을 서서 히 감소시킨다.

$$
E_{i}= \begin{cases}0 & : i=x \text { or } y \\ \beta w & : i=z\end{cases}
$$

개경계 조건은 수치파동수조에서 생성된 에너지를 수조 밖으 로 완벽하게 배출하기 위한 것으로 식 (16)처럼 Hinatsu(1992)의 개경계 처리법을 이용한다. 식 (16)에서 $\phi$ 는 유속과 같은 물리 량을 말한다.

$$
\frac{\partial \phi}{\partial t} \pm C \frac{\partial \phi}{\partial x_{i}}=0
$$

\section{3. 수치모델의 검증}

\section{1 검증을 위한 수치파동수조의 구성 및 조건}

LES-WASS-3D ver. 2.0을 적용한 연구들에서는 파랑의 진행 방향 양쪽에 무반사 조파시스템을 적용하였다(Lee et al., 2017; Lee et al., 2018). 그러나 수중발파에 의한 수면파는 사방으로 전파된다. 따라서 수중발파에 의한 수면파 전파모의에 앞서 이 용하는 수치파동수조의 검증이 요구된다.

Fig. 4와 같이 구성된 수치파동수조의 정중앙에서 발파에 의한 수면파를 생성하여 그 전파과정을 경험적 값과 비교 분석한다. $1 \mathrm{~km} \times 1 \mathrm{~km} \times 15 \mathrm{~m}$ 해석영역을 설정하여 수평 격자 $(\Delta x, \Delta y)$ 는 $5 \mathrm{~m}$, 수직 격자 $(\Delta z)$ 는 $0.5 \mathrm{~m}$ 의 수치파동수조를 구 성하며, 그 외곽에는 Fig. 3 과 같이 부가감쇠영역 및 개경계 조건을 고려한다.

이용하는 계산조건은 Table 1과 같으며, 토도 제거를 위한 수 중발파 시나리오를 그대로 적용하여 수치파동수조를 검증한다. 수중발파 시나리오의 단계는 수심 $-1 \mathrm{~m},-6 \mathrm{~m},-11 \mathrm{~m},-15 \mathrm{~m}$ 순으로

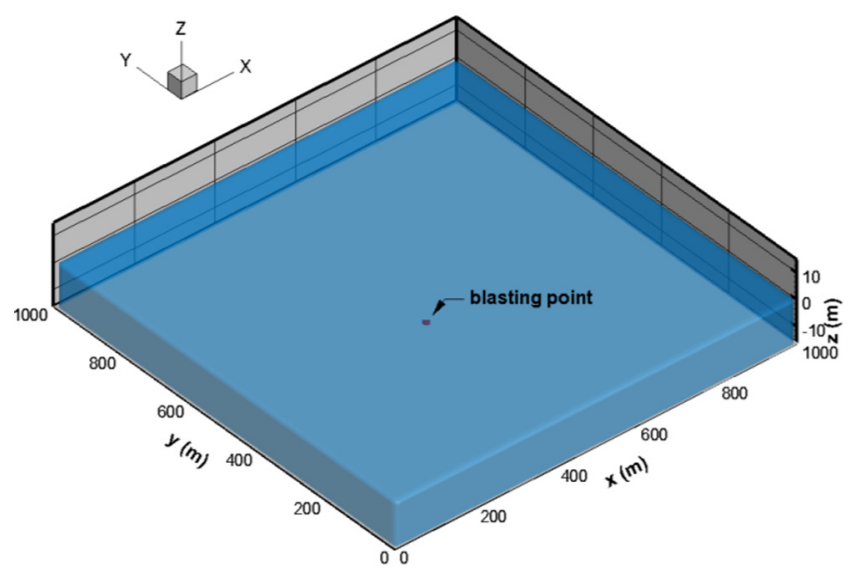

Fig. 4 Definition sketch of a 3-D numerical water tank for validation

Table 1 Underwater blasting conditions used in numerical model validation

\begin{tabular}{ccccc}
\hline Scenario & $\begin{array}{c}z \\
{[\mathrm{~m}]}\end{array}$ & $\begin{array}{c}\text { Charge weight } \\
\text { per hole } \\
{[\mathrm{kg} / \mathrm{hole}]}\end{array}$ & $\begin{array}{c}\text { Number } \\
\text { of holes }\end{array}$ & $\begin{array}{c}\text { Total charge } \\
\text { weight } \\
{[\mathrm{kg}]}\end{array}$ \\
\hline S1 & 1 & 124 & & 124 \\
S2 & 6 & 90 & 1 & 90 \\
S3 & 11 & 58 & & 58 \\
S4 & 15 & 25 & & 25 \\
\hline M1 & 1 & 52 & 10 & 520 \\
M2 & 6 & 42 & 11 & 462 \\
M3 & 11 & 27 & 15 & 405 \\
M4 & 15 & 12 & 30 & 360 \\
\hline
\end{tabular}

진행한다. 그리고 단일발파(Scenario S1-S4)와 다중발파(Scenario M1-M4)로 구분하여 수중발파에 따른 수면파의 생성 및 전파를 모의한다. 다중발파에서 발파공의 간격은 $5 \mathrm{~m}$ 이다. 그리고 모든 수 치모의의 초기계산간격 $(\Delta t)$ 을 $1 / 100$ 초로 설정하고, CFL(CourantFriedrichs-Lewy)조건을 만족하게 조절한다.

\section{2 수면파의 비교 · 검증}

Fig. 5는 단일발파, Fig. 6은 다중발파에 의해 발생한 수면파가 초기 수면형의 반경 $(R)$ 에서 $500 \mathrm{~m}$ 까지 전파하는 과정에서의 최 대수위를 비교한 것이다. 여기서 검정 실선은 식 (4)에 의한 값, 붉은 동그라미는 수면파의 최대수위를 각각 나타낸다.

Fig. 5와 Fig. 6에서 각각의 $R$ 지점에서 경험식 (4)에 의한 값과 수치모의결과 매우 잘 일치함을 알 수 있다. 이것은 발파지점(조 파원천)에서 발생하는 수면파의 생성과정이 타당하기 때문이다. 또한 $R$ 지점에서 $500 \mathrm{~m}$ 지점까지 수면파가 전파되는 과정에서 최 대수위가 높은 정확도로 일치한다. 이것은 본 연구에서 수치파 동수조가 발파에 의한 수면파 전파모의에 적합함을 보여준다.

이로써 본 연구에서 제안한 수중폭파에 의한 수면파의 생성 방법, 수치파동수조에서의 수면파 전파모의에 대한 타당성 및 유효성이 입증되었다. 


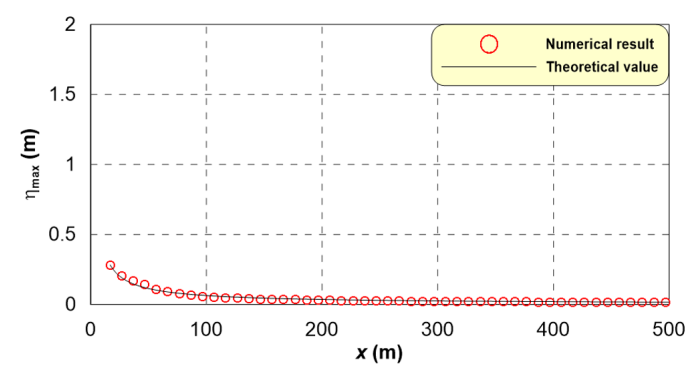

(a) Scenario S1

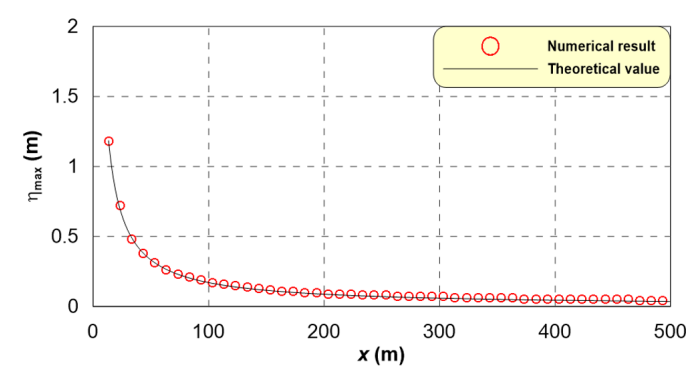

(c) Scenario S3

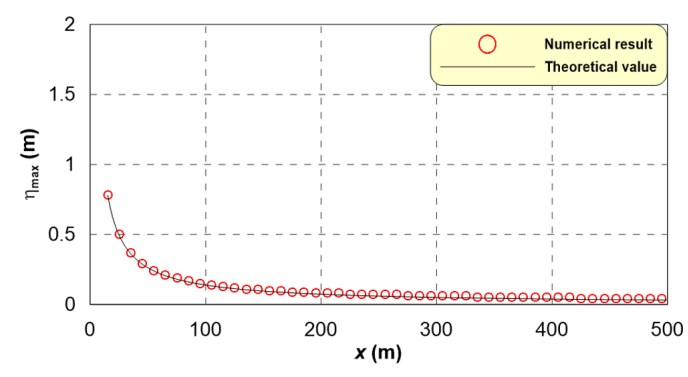

(b) Scenario S2

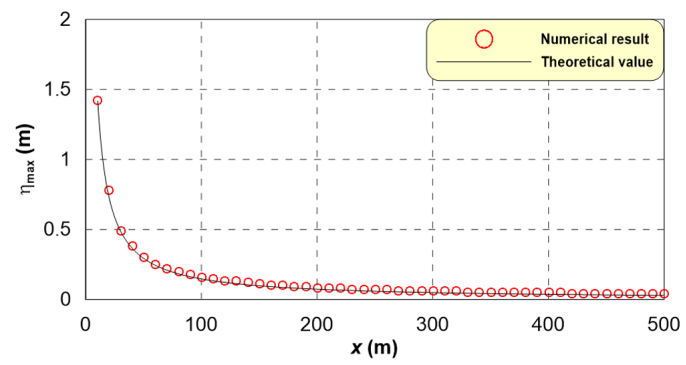

(d) Scenario S4

Fig. 5 Comparisons between theoretical(red circle) and numerical(black line) results showing the maximum elevation of water wave by a single-charge blasting

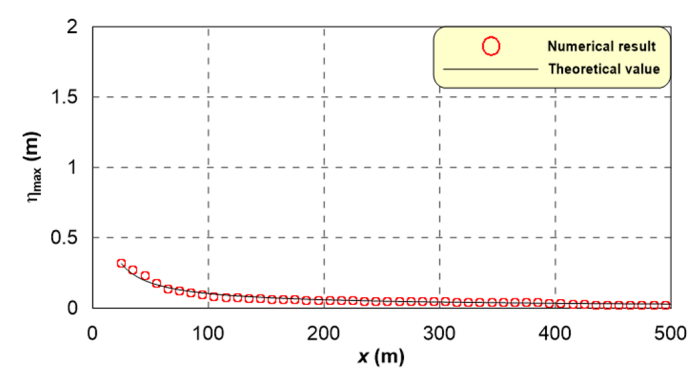

(a) Scenario M1

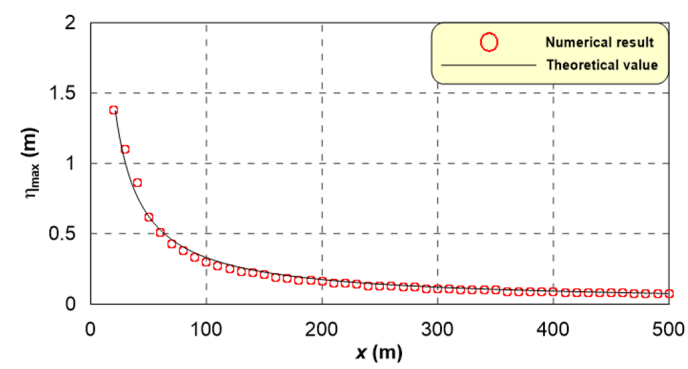

(c) Scenario M3

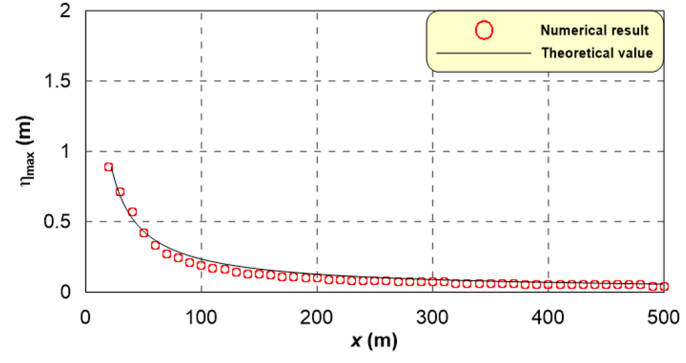

(b) Scenario M2

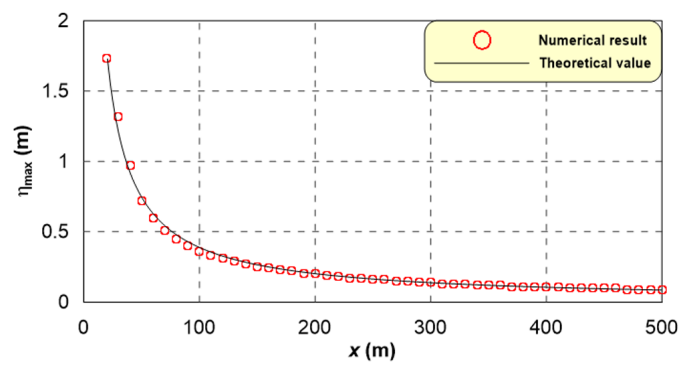

(d) Scenario M4

Fig. 6 Comparisons between theoretical value and numerical result showing the maximum elevation of water wave by a multiple-charge blasting

\section{4. 수치모의}

\section{1 수치파동수조의 구성 및 조건}

본 연구에서는 토도 제거를 위한 수중발파 시나리오별 수면파의 생성 및 전파를 모의하기 위하여 Fig. 7에 나타낸 부산신항만의 전 해역을 수치파동수조의 계산영역으로 설정한다. Table 2에 나타낸 것과 같이 $5.91 \mathrm{~km} \times 2.71 \mathrm{~km} \times 23 \mathrm{~m}$ 의 계산영역을 수평 방향으로 $5 \mathrm{~m}$ 등간격 분할하고, 수직 방향으로 $0.1-0.5 \mathrm{~m}$ 부등간격 분할한다. 이 과정에서 부산신항만 내의 경사지형은 Hur et al.(2008)의 경사면
처리기법을 적용한다. 나머지 상세한 수치모의조건은 Table 2 과 같다. 단계별 수중발파 시나리오는 Table 1과 같으며, 육상제거가 완료된 수심 $-1 \mathrm{~m}$ 를 시작하여 수심 $-6 \mathrm{~m}$, 수심 $-11 \mathrm{~m}$ 그리고 마지 막으로 수심 $-15 \mathrm{~m}$ 까지 Table 3 과 같이 총 4 단계로 나누어 수치 모의를 수행한다. 수중발파 시나리오별 장약량은 Table 1에서 기술한 바와 같다. 발파지점에 따른 수면파의 영향 검토는 수치 파동수조 검증에서 가장 큰 수면변동이 발생한 다중발파의 시 나리오 4단계 조건(Scenario M4; 수심 $-15 \mathrm{~m}$ )에서 동서남북 가장 자리를 발파지점으로 한다(Table 4 참조). 그리고 부산신항만 컨 


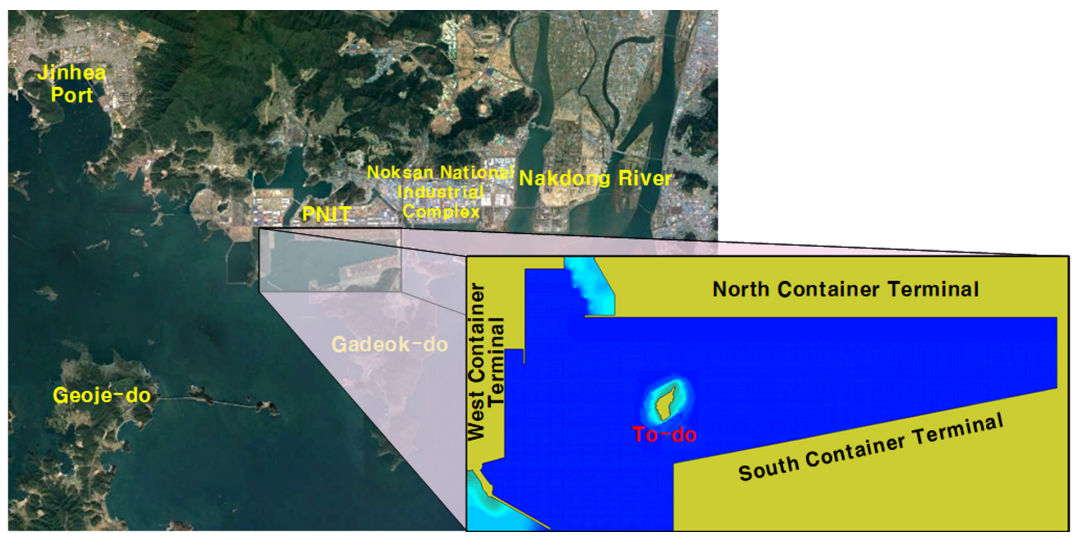

Fig. 7 Overview of target area (Pusan Newport International Terminal, Busan, Korea)

Table 2 Operating conditions for numerical simulation

\begin{tabular}{ll}
\hline \hline Domain size & $5.91 \mathrm{~km} \times 2.71 \mathrm{~km} \times 23 \mathrm{~m}$ \\
Grid size & $\Delta x$ or $\Delta y=5 \mathrm{~m}, \Delta z=0.1-0.5 \mathrm{~m}$ \\
Grid number & $46,126,368(1182 \times 542 \times 72)$ \\
Time step & $1 / 100 \mathrm{~s}$ \\
Computing time & $10 \mathrm{~min}$ \\
Offshore boundary & Added dissipation zone with open boundary \\
Bottom boundary & Non-slip condition \\
Water level & Mean sea level (MSL) \\
\hline
\end{tabular}

테이너 터미널에서 미치는 영향을 정량적으로 검토하기 위하여 동서남북 직선거리가 가장 가까운 터미널의 4지점에서 시간파 형을 측정한다(Table 5 참조).

\section{2 수면파의 전파}

Fig. 8과 Fig. 9는 다중발파에 의해 생성된 수면파가 전파하는 과정을 30 초 간격으로 나타낸 공간파형이다. Fig. 8은 Scenario M1 으로서 발파수심 $1 \mathrm{~m}$ 에 총 장약량이 $520 \mathrm{~kg}$, Fig. 9는 Scenario M4로 서 발파수심 $-15 \mathrm{~m}$, 총장약량이 $360 \mathrm{~kg}$ 의 경우를 각각 나타낸다.

Table 3 Scenarios of underwater blasting for numerical simulation

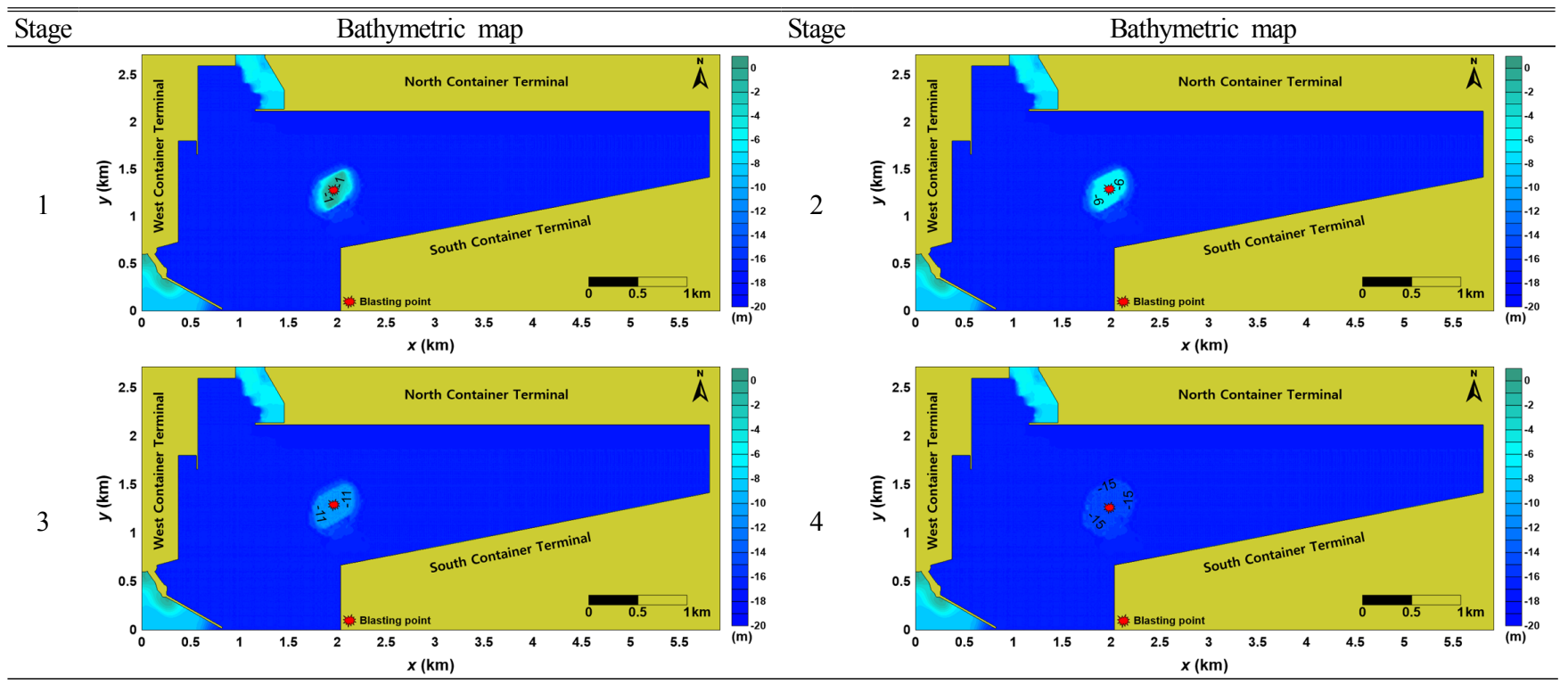

Table 4 Underwater blasting points under condition of stage 4

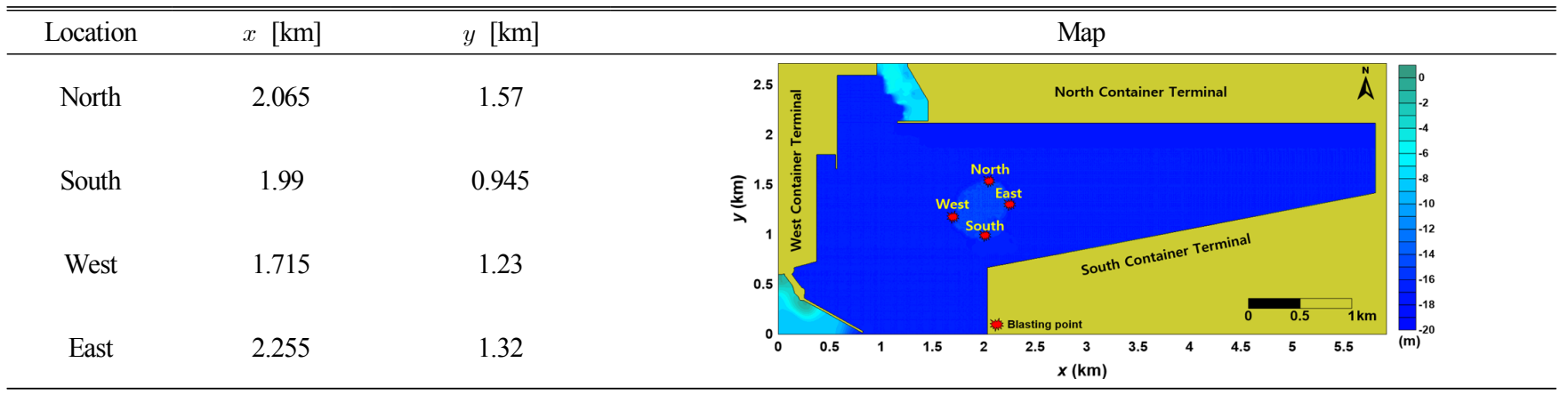


Table 5 Measuring points of water wave by underwater blasting

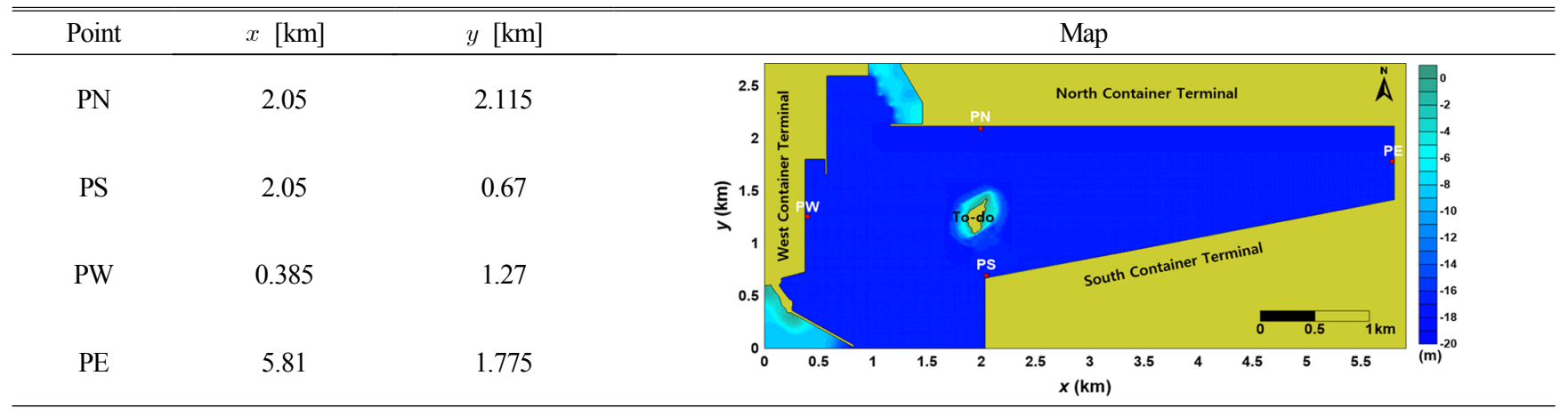

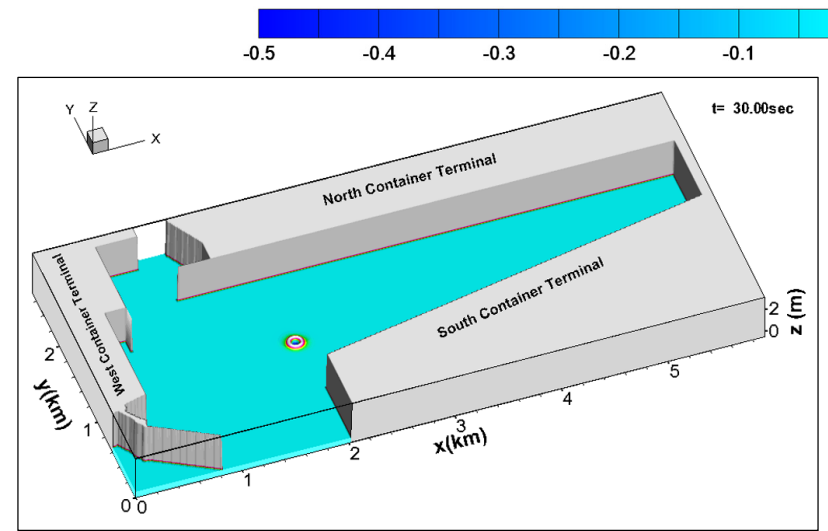

(a) $t=30 \mathrm{~s}$

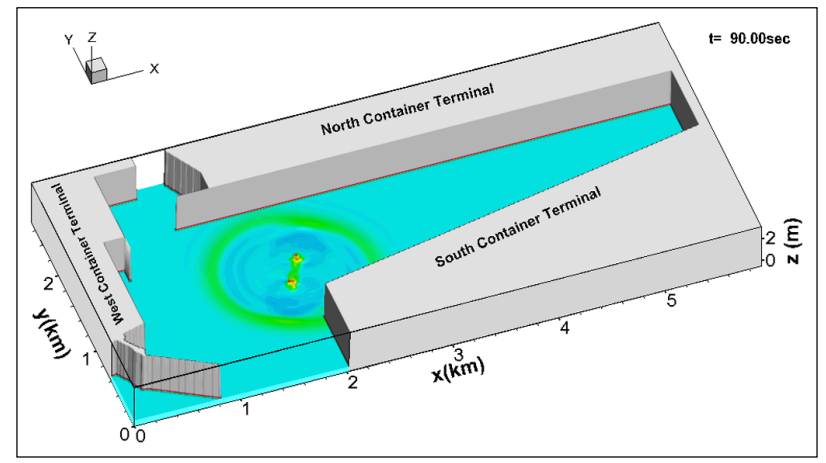

(c) $t=90 \mathrm{~s}$

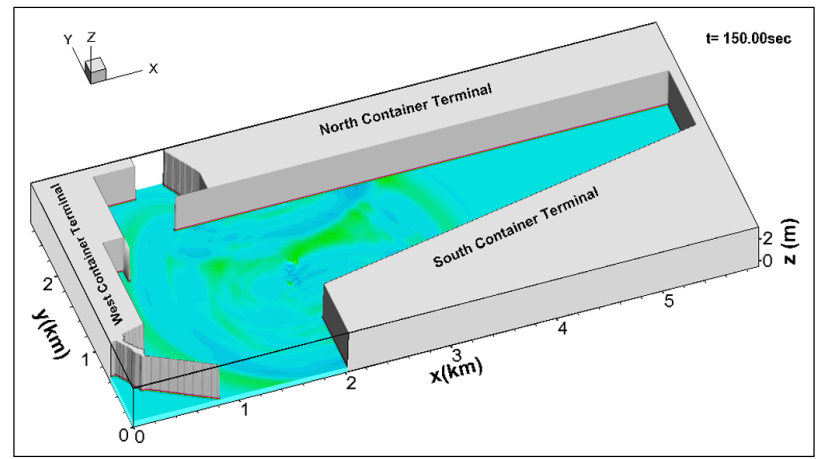

(e) $t=150 \mathrm{~s}$

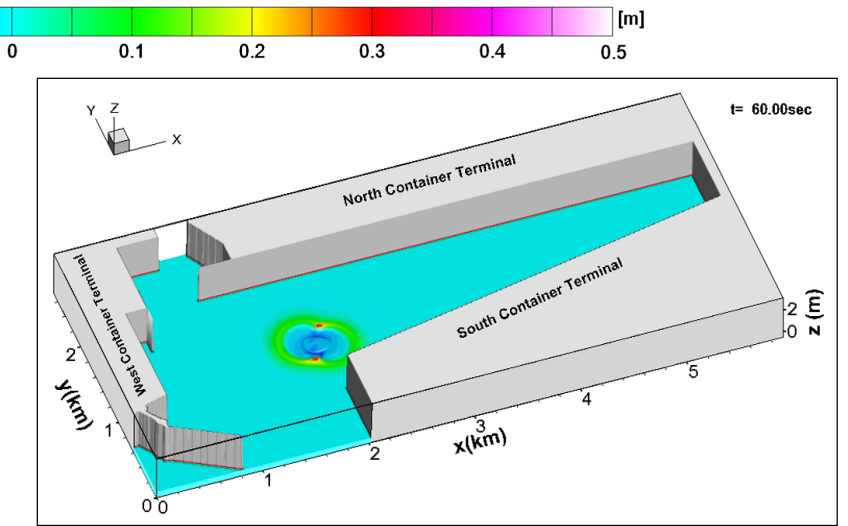

(b) $t=60 \mathrm{~s}$

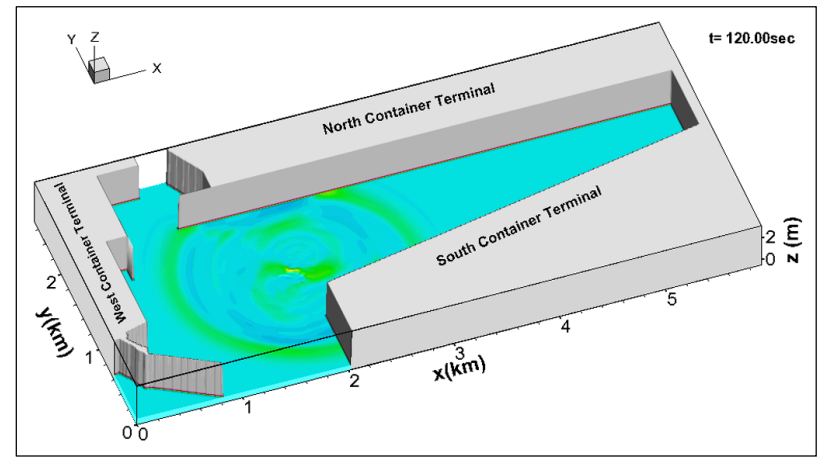

(d) $t=120 \mathrm{~s}$

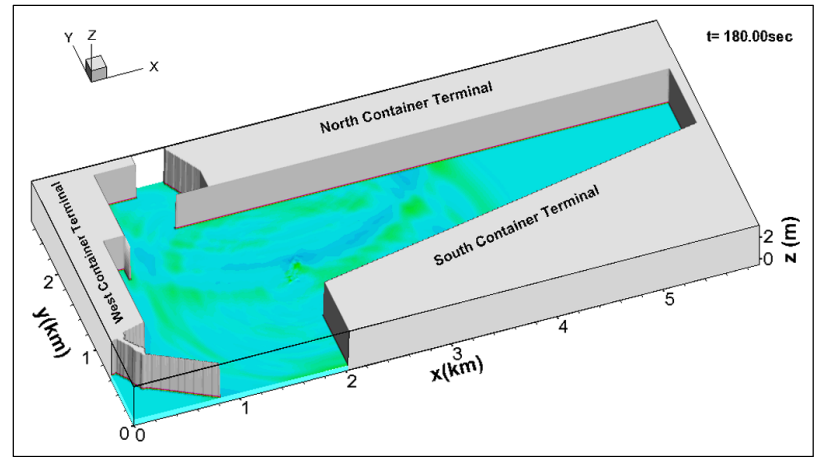

(f) $t=180 \mathrm{~s}$

Fig. 8 Temporal and spatial distributions of water surface elevations by underwater blasting in case of Scenario M1

Fig. 8에서는 장약량이 가장 많음에도 불구하고, 발파수심이 $-1 \mathrm{~m}$ 로 낮으므로 폭파에너지가 얇은 수층으로 전달됨으로 발생 하는 수면파의 진폭이 작다. 그 뿐 아니라 수심 $-1 \mathrm{~m}$ 의 토도 지
형이 남북으로 긴 타원형인 관계로 방사형으로 전파되던 수면 파가 남북방향의 양쪽에서 굴절되어 수면파의 중첩이 발생한다. 반면에 Fig. 9에서는 발파수심이 $-15 \mathrm{~m}$ 로 가장 깊으므로 장약량 


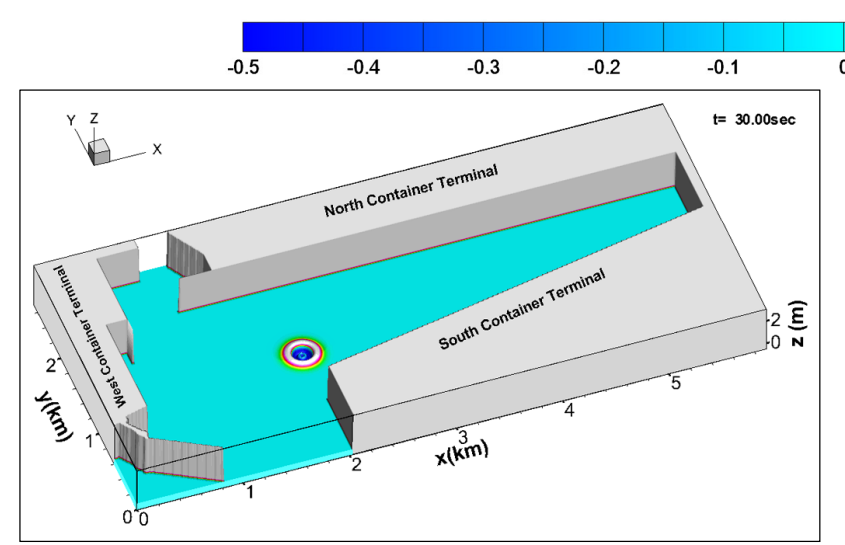

(a) $t=30 \mathrm{~s}$

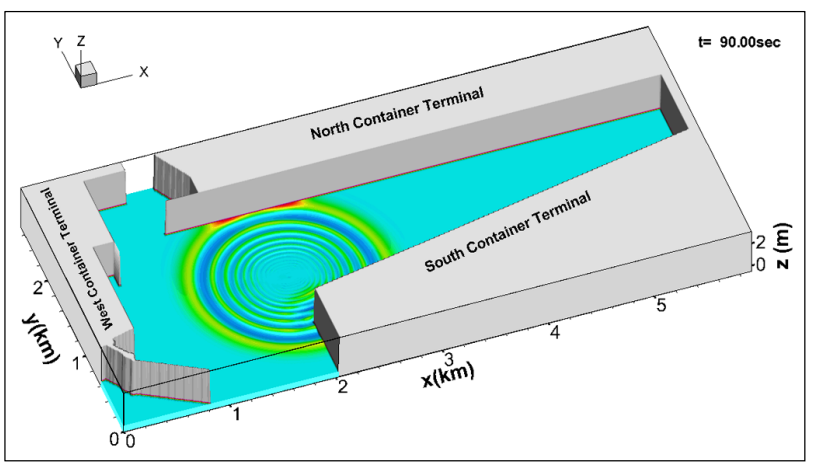

(c) $t=90 \mathrm{~s}$

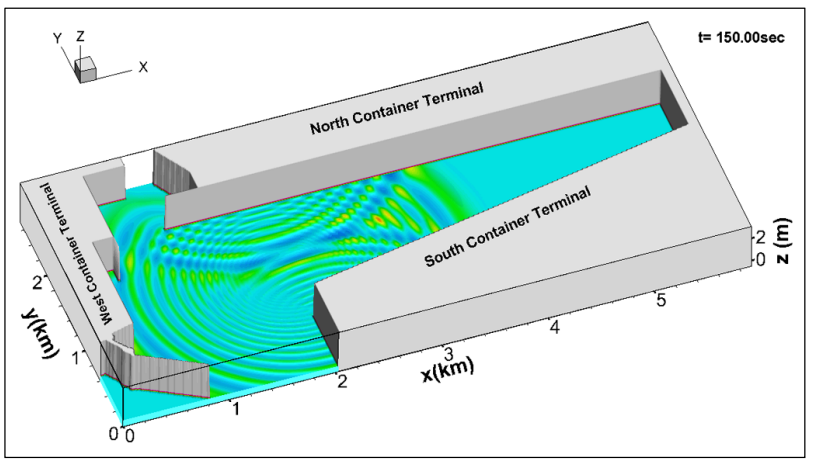

(e) $t=150 \mathrm{~s}$

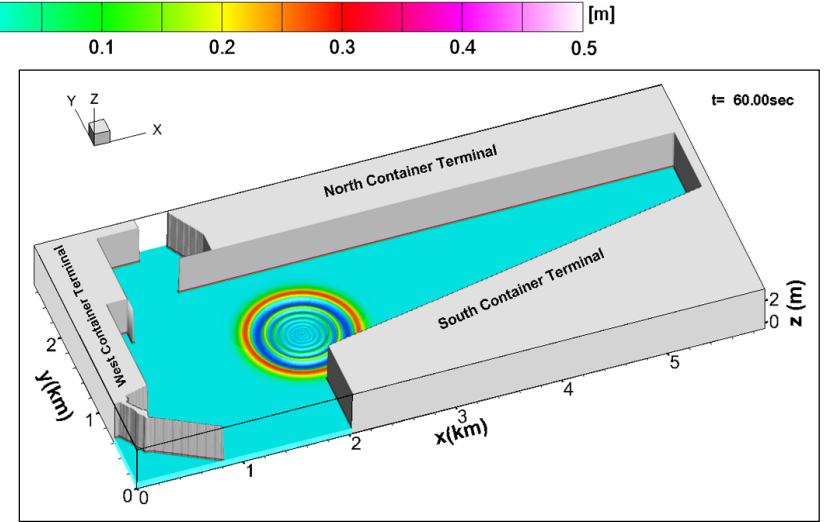

(b) $t=60 \mathrm{~s}$

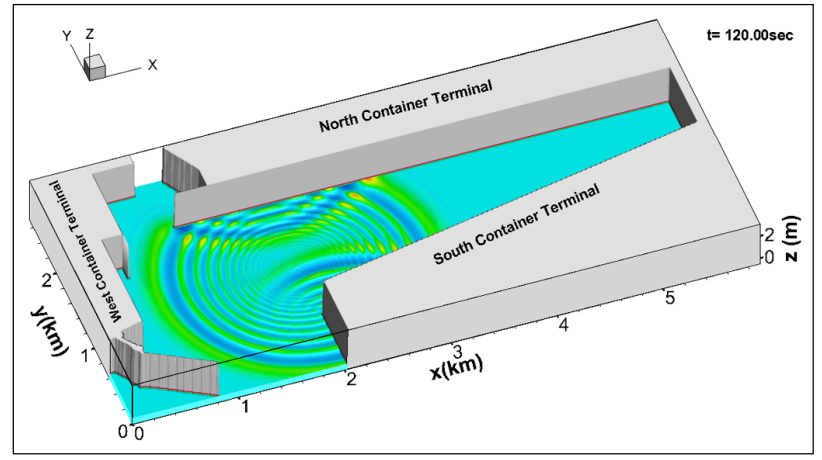

(d) $t=120 \mathrm{~s}$

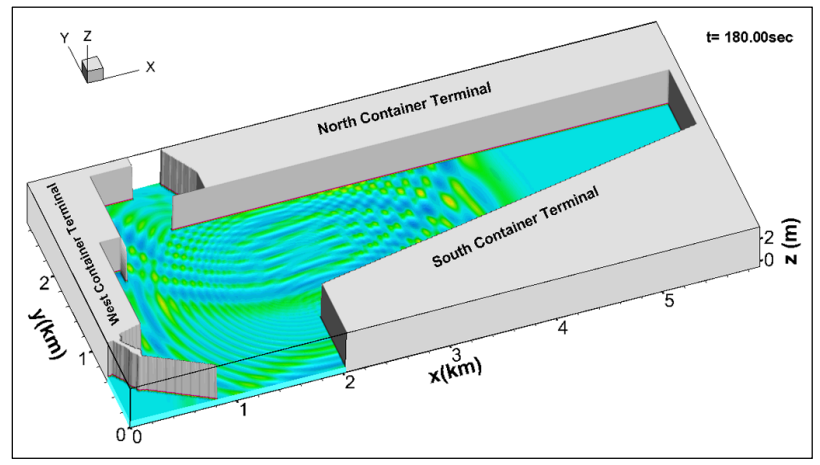

(f) $t=180 \mathrm{~s}$

Fig. 9 Temporal and spatial distributions of water surface elevations by underwater blasting in case of Scenario M4

이 적음에도 폭파에너지가 전 수층으로 전달됨으로 수면파의 진폭이 크다. 또한 수면파의 전파에 있어서 토도의 지반높이 $(-15 \mathrm{~m})$ 와 항로의 수심(-17m)과 차이가 작은 관계로 방사형으로 그대로 퍼져나간다. 이 과정에서 수면파는 가까운 남쪽과 북쪽 의 컨테이너 터미널 그리고 서쪽 컨테이너 터미널 순으로 도달 한다. 그리고 컨테이너 터미널 안벽에 의한 반사파 간의 중첩이 연속적으로 발생함을 알 수 있다.

Fig. 10과 Fig. 11은 Table 5에 나타낸 PN, PS, PW, PE에서의 시간파형이며, 수중발파지점에서 직선거리가 가장 가까운 다목 적 터미널, 남, 서, 북 컨테이너 터미널의 한 지점이다. 여기서 Fig. 10은 Scenario M1, Fig. 11은 Scenario M4의 경우이다.

Fig. 10과 Fig. 11로부터 수중발파지점으로부터 직선거리가 가 까운 PS, PN, PW, PE 순으로 수면변위가 나타난다. Fig. 10은 전술한 Fig. 8 에서 논의한 것과 같이 전체적으로 수면변위가 크
지 않다. Fig. 11은 상대적으로 수면변위가 크고, PS, PN, PW, $\mathrm{PE}$ 순으로 수면파의 파고가 큰 것을 알 수 있다.

Table 6 Travel time of water wave by underwater blasting in each of measuring points

\begin{tabular}{ccccc}
\hline \multirow{2}{*}{ Scenario } & \multicolumn{4}{c}{ Measuring point [s] } \\
\cline { 2 - 5 } & PN & PS & PW & PE \\
\hline S1 & 100.5 & 86 & 156.5 & 339 \\
S2 & 92 & 75 & 150.5 & 330 \\
S3 & 88.5 & 70 & 145.5 & 326 \\
S4 & 86 & 68 & 147.5 & 320 \\
M1 & 101.5 & 84 & 157.5 & 337 \\
M2 & 92.5 & 74.5 & 151 & 329 \\
M3 & 89 & 69.5 & 146 & 326 \\
M4 & 86.5 & 67.5 & 148 & 319.5 \\
\hline
\end{tabular}



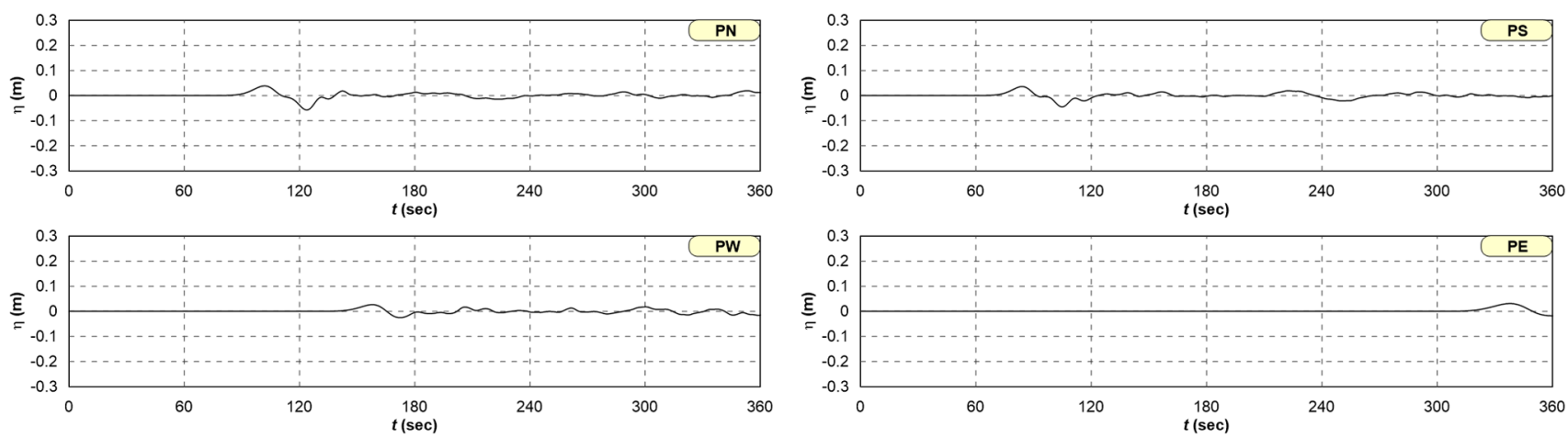

Fig. 10 Time-domain waveform under multiple-charge blasting for Scenario M1
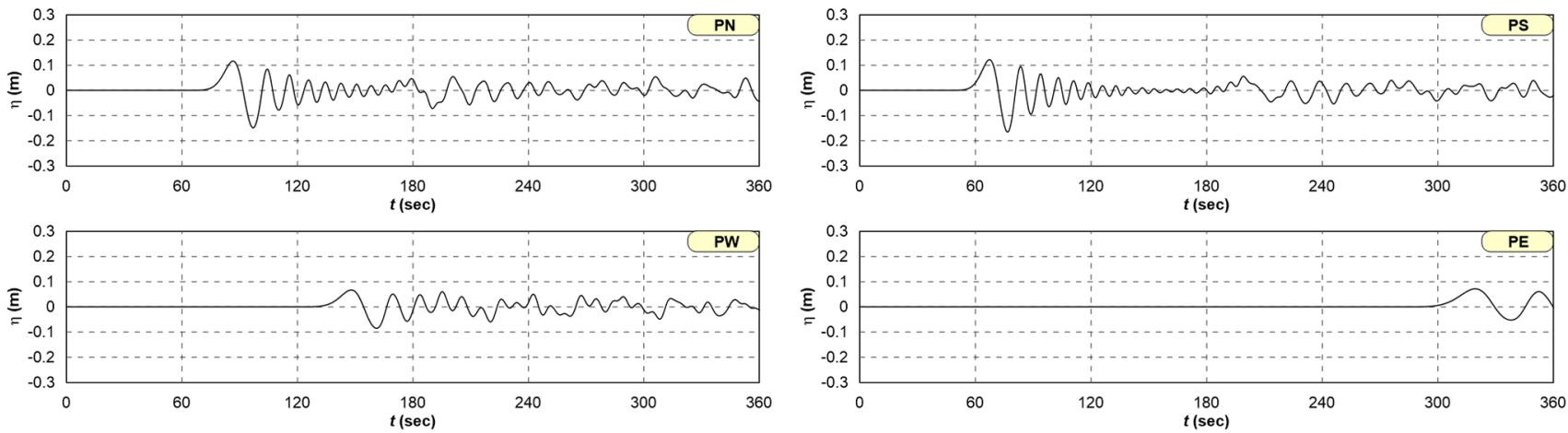

Fig. 11 Time-domain waveform under multiple-charge blasting in Scenario M4

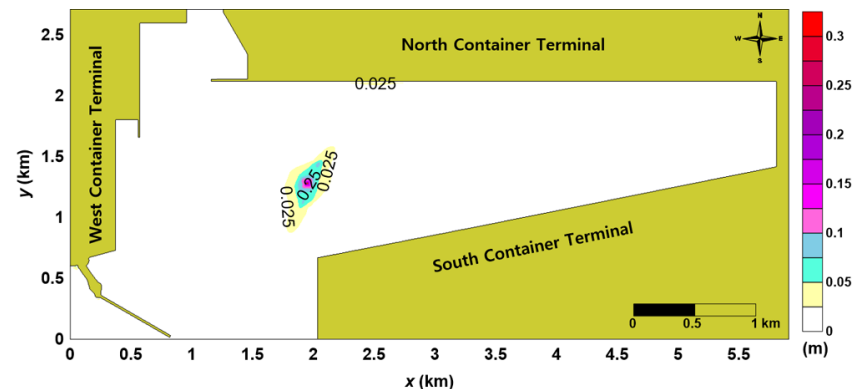

(a) Scenario S1

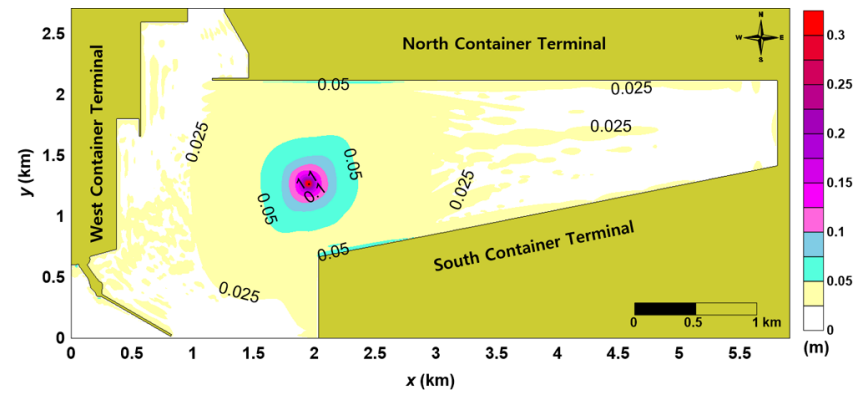

(c) Scenario S3

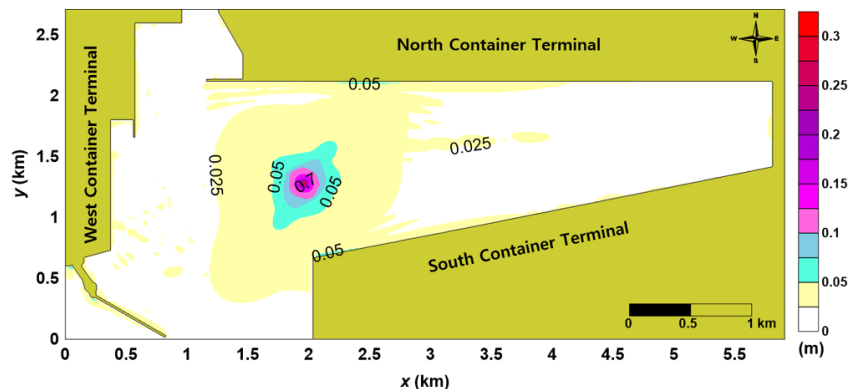

(b) Scenario S2

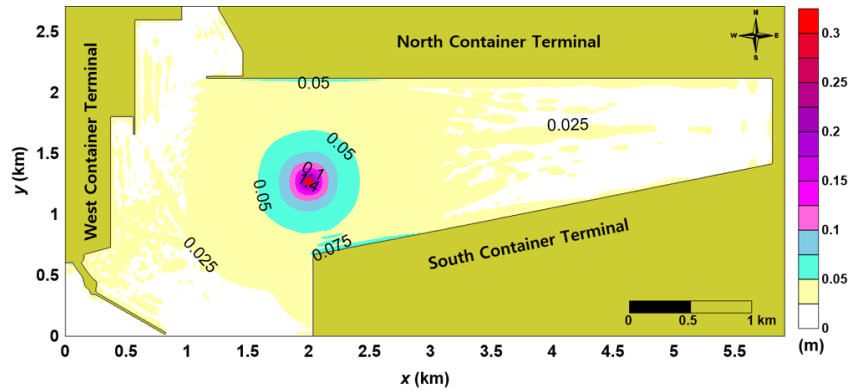

(d) Scenario S4

Fig. 12 Spatial distributions of maximum elevation of water wave by a single-charge blasting

Table 6은 수중발파 시나리오별 PS, PN, PW, PE에서의 최대수 위 $\left(\eta_{\max }\right)$ 가 발생하는 시간을 각각 나타낸 것이다. 전술처럼 수 중발파지점으로부터 직선거리가 가까운 $\mathrm{PS}, \mathrm{PN}, \mathrm{PW}, \mathrm{PE}$ 순으로 수면파가 도달한다. 그리고 단일발파 및 다중발파에서 발파수심 이 깊어 수면파동이 큰 시나리오(Scenario S4와 M4)에서 각각의 안벽에 도달하는 시간이 빨라진다. 이것은 Dean and Dalrymple
(1991)의 고립파 근사이론과 같이 수심과 수면변위가 클수록 파 속(식 (14))이 빠르기 때문이다.

\section{3 최대수위분포}

Fig. 12 는 단일 수중발파에서 시나리오별 최대수위 $\left(\eta_{\max }\right)$ 의 공 간분포를 나타낸다. Fig. 12에서 (a), (b), (c), (d)는 Scenario S1-S4 


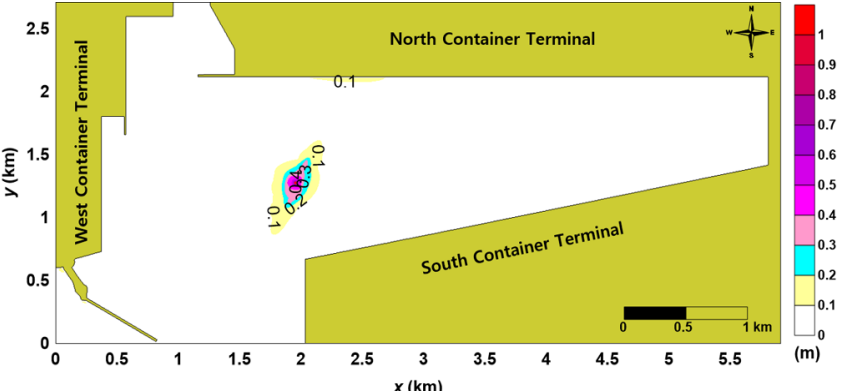

(a) Scenario M1

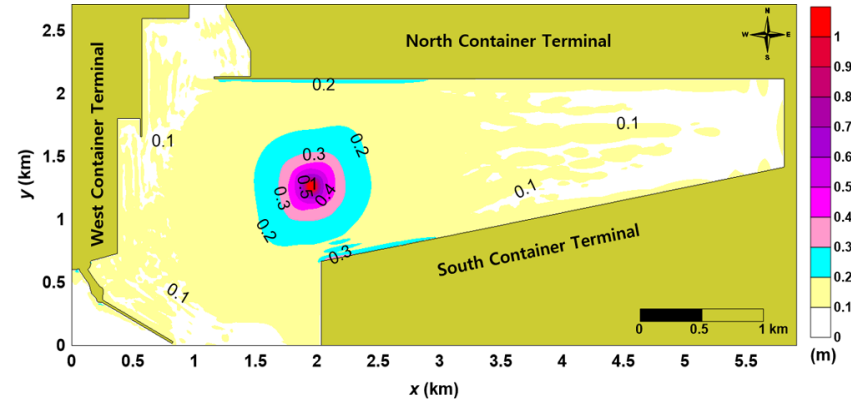

(c) Scenario M3

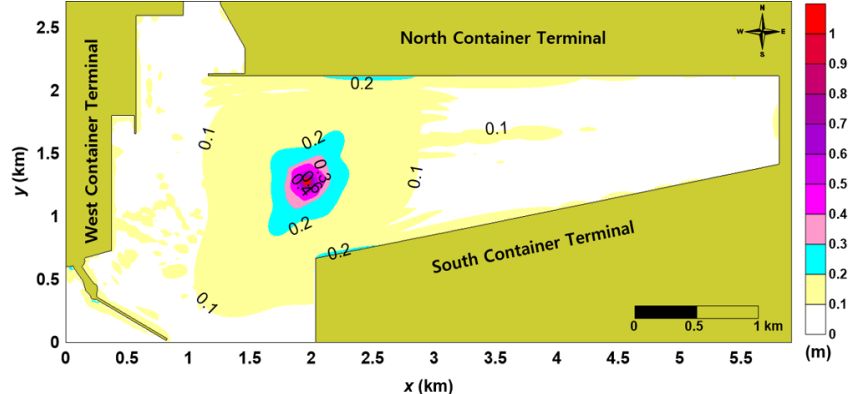

(b) Scenario M2

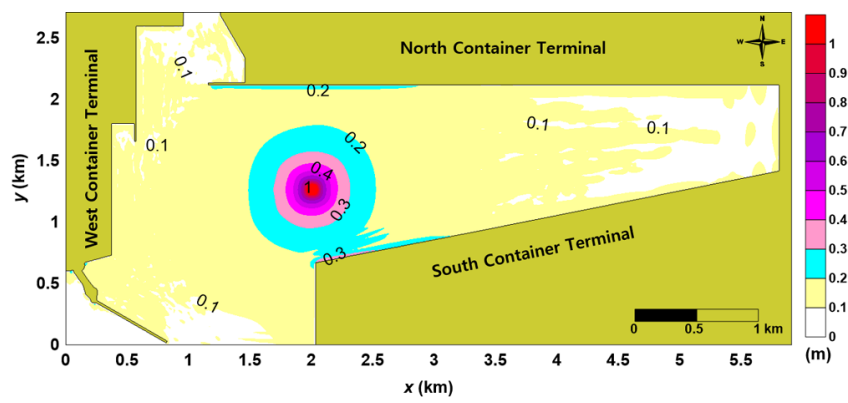

(d) Scenario M4

Fig. 13 Spatial distributions of maximum elevation of water wave by a multiple-charge blasting

를 나타내며, 발파수심은 $-1 \mathrm{~m},-6 \mathrm{~m},-11 \mathrm{~m},-15 \mathrm{~m}$, 장약량은 $124 \mathrm{~kg}$, $90 \mathrm{~kg}, 58 \mathrm{~kg}, 25 \mathrm{~kg}$ 이다.

Fig. 12로부터 장약량이 많음에도 불구하고, Scenario S1에서 가장 작은 $\eta_{\max }$ 가 발생하는 것은 발파수심이 낮아 수중발파에 의 한 수면파동이 발달하지 못하기 때문이며, Fig. 8을 통해 확인할 수 있었다. 따라서 발파수심이 깊을수록 수중발파에 의한 $\eta_{\max }$ 가 증가하고, 영향 범위도 증가함을 알 수 있다.

Fig. 13은 다중 수중발파에서 시나리오별 $\eta_{\max }$ 의 공간분포이 며, (a), (b), (c), (d)는 Scenario M1-M4를 나타내며, 발파수심은 $-1 \mathrm{~m},-6 \mathrm{~m},-11 \mathrm{~m},-15 \mathrm{~m}$, 장약량은 $520 \mathrm{~kg}, 462 \mathrm{~kg}, 405 \mathrm{~kg}, 360 \mathrm{~kg}$ 이다.

Fig. 13을 Fig. 12와 비교하면, 같은 발파수심에서 장약량이 많 은 다중발파의 경우(즉, Fig. 12보다 Fig. 13)에 $\eta_{\max }$ 가 클 뿐 아 니라, 수면파의 영향 범위도 넓어진다. 한편 발파수심이 $15 \mathrm{~m}$ 인 Scenario S4와 M4를 직접 비교하면, Scenario M4가 장약량이 14.4배 많음에도 $\eta_{\max }$ 와 영향 범위가 많이 증가하지 않는다. 이것은 $\mathrm{Le}$ Méhauté and Wang(1996)의 제안식 (4)에서도 알 수 있듯이 장약 량 $(W)$ 에 따른 $\eta_{\max }$ 의 변화가 크지 않기 때문이다.

부산신항만 컨테이너 터미널에 미치는 영향을 정량적으로 분 석하기 위하여 Table 5에 나타낸 각각의 터미널의 측정지점 $\mathrm{PN}$, $\mathrm{PS}, \mathrm{PW}, \mathrm{PE}$ 에서의 $\eta_{\max }$ 를 Table 7 에 나타낸다.

Table 7로부터 알 수 있듯이 단일 수중발파 Scenario S1-S4는 부산신항만 컨테이너 터미널에 미치는 영향이 미미하다. 그리고 다 중발파에서 가장 큰 수면파동이 발생하는 Scenario M4의 경우에 직 선거리가 가장 짧은 남컨테이너 터미널 $\mathrm{PS}$ 지점의 $\eta_{\max }$ 는 $0.29 \mathrm{~m}$ 로 그렇게 크지 않다.

본 연구에서 검토한 단일발파 및 다중발파 그리고 단계별 시나리 오에 따른 수면파는 주변 컨테이너 터미널에 미치는 영향이 그다지 크지 않다. 하지만 수중발파지점이 터미널에 가까울수록 $\eta_{\max }$ 가 증
Table 7 Maximum elevation of water wave by underwater blasting in each of measuring points

\begin{tabular}{ccccc}
\hline \multirow{2}{*}{ Scenario } & \multicolumn{4}{c}{ Measuring point [m] } \\
\cline { 2 - 5 } & PN & PS & PW & PE \\
\hline S1 & 0.02 & 0.02 & 0.01 & 0.01 \\
S2 & 0.04 & 0.04 & 0.03 & 0.03 \\
S3 & 0.05 & 0.06 & 0.03 & 0.03 \\
S4 & 0.06 & 0.06 & 0.03 & 0.03 \\
M1 & 0.1 & 0.08 & 0.05 & 0.03 \\
M2 & 0.19 & 0.19 & 0.12 & 0.12 \\
M3 & 0.24 & 0.26 & 0.15 & 0.13 \\
M4 & 0.27 & 0.29 & 0.15 & 0.12 \\
\hline
\end{tabular}

가하는 경향이 나타남으로 Table 4의 발파지점에 따른 수면파의 특 성을 다음에서 검토한다.

\section{4 발파지점별 수면파의 전파}

Fig. 14는 Table 7에서 가장 큰 $\eta_{\max }$ 가 발생한 Scenario M4에 서 Table 4에 표시한 발파지점별 $\eta_{\max }$ 의 공간분포를 나타낸다. Fig. 14에서 (a)는 북쪽, (b)는 남쪽, (c)는 서쪽, (d)는 동쪽 각각 의 가장자리에서 수중발파를 진행한 결과이다.

Fig. 14로부터 동쪽의 다목적 터미널을 제외하고는 수중발파 지점에 인접할수록 남쪽, 북쪽, 서쪽 컨테이너 터미널에서 전반 적으로 $\eta_{\max }$ 가 상승하고, 영향 범위가 넓어지는 경향을 보인다. 이것은 수중발파에 의한 수면파가 방사형으로 전파되기 때문에 영향권을 벗어나는 경우엔 $\eta_{\max }$ 가 매우 작지만, 그렇지 않으면 컨테이너 터미널 안벽에서 유의미한 $\eta_{\max }$ 가 발생함을 알 수 있 


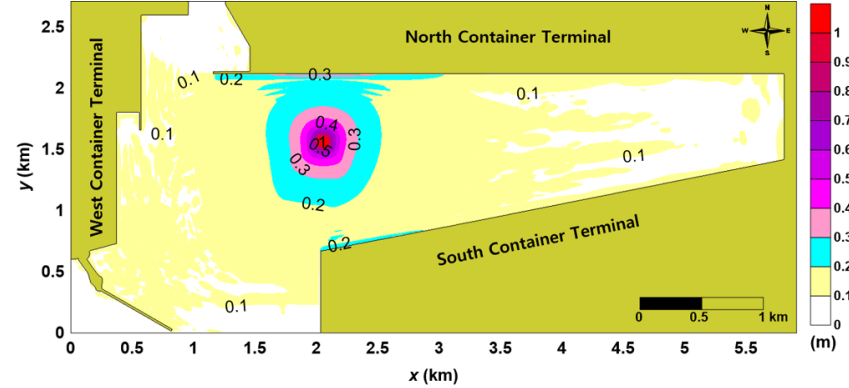

(a) North

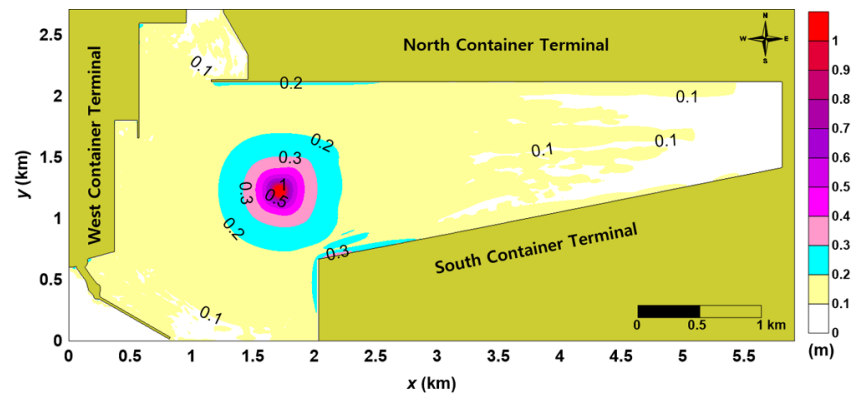

(c) West

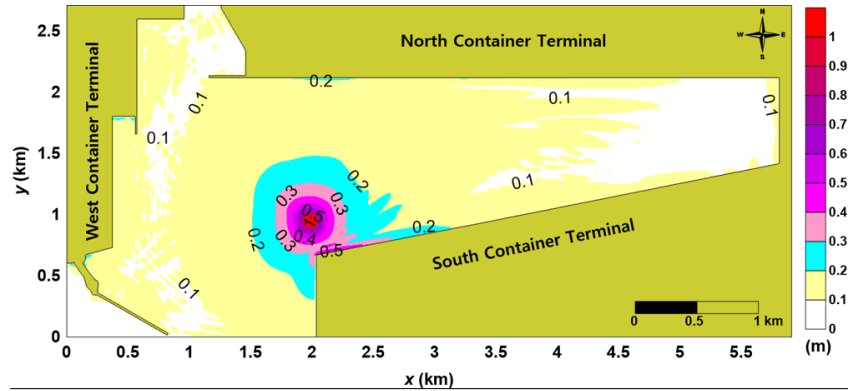

(b) South

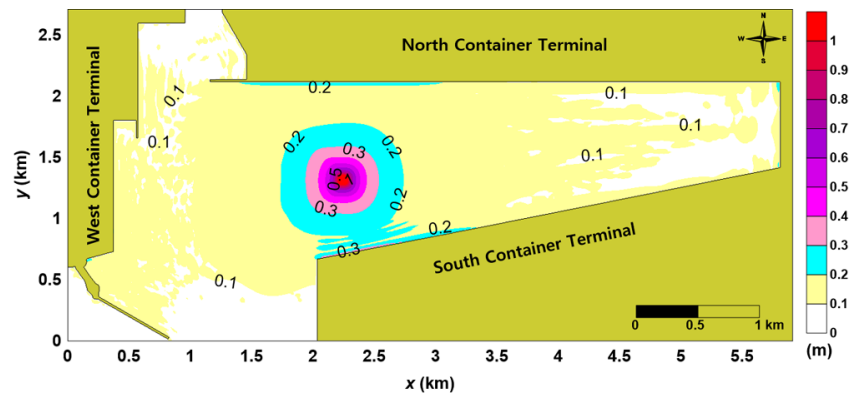

(d) East

Fig. 14 Spatial distributions of maximum elevation of water wave due to blasting positions

Table 8 Maximum elevation of water wave in each of blasting positions

\begin{tabular}{ccccc}
\hline \hline \multirow{2}{*}{ Position } & \multicolumn{4}{c}{ Measuring point $[\mathrm{m}]$} \\
\cline { 2 - 5 } & PN & PS & PW & PE \\
\hline Center & 0.27 & 0.29 & 0.15 & 0.12 \\
North & 0.36 & 0.21 & 0.15 & 0.1 \\
South & 0.21 & 0.49 & 0.14 & 0.12 \\
West & 0.23 & 0.26 & 0.17 & 0.07 \\
East & 0.25 & 0.24 & 0.14 & 0.15 \\
\hline
\end{tabular}

다. 이에 정량적 분석을 위해 Table 8 에 각 컨테이너 터미널의 측정지점 $\mathrm{PN}, \mathrm{PS}, \mathrm{PW}, \mathrm{PE}$ 에서의 $\eta_{\max }$ 를 나타낸다.

Table 8 로부터 각 컨테이너 터미널로부터 수중발파지점이 가 까운 경우, $\eta_{\max }$ 가 증가한다. 특히, 토도로부터 직선거리가 가까 운 남과 북의 컨테이너 터미널에서 $\eta_{\max }$ 가 증가하며, 남쪽 발파 시에 $\mathrm{PS}$ 에서 $0.2 \mathrm{~m}$, 북쪽 발파 시에 $\mathrm{PN}$ 에서 $0.09 \mathrm{~m}$ 크다. 그리고 토도와 거리가 상대적으로 먼 서쪽 컨테이너 터미널과 다목적 터미널의 측정지점 $\mathrm{PW}$ 와 $\mathrm{PN}$ 에서는 $\eta_{\max }$ 의 증가가 크지 않다.

\section{5. 결론 및 고찰}

본 연구에서는 수중발파에 의한 수면파의 발생 및 전파를 모 의하기 위하여 3차원 수치파동수조(LES-WASS-3D Ver. 2.0; Lee and Hur, 2014a)를 개량하였다. 그 과정에서 수중발파에 의한 수 면파를 생성을 위하여 발파수심과 장약량에 따라 파 제원을 추 정할 수 있는 경험식을 수면파 조파에 이용하였다. 그리고 수치 파동수조에서 수중발파에 따른 수면파의 생성과 전파 과정에서 의 최대수위분포를 비교 - 검증하였다. 이 수치파동수조에 토도
제거를 위한 수중발파 시나리오를 적용하여 수면파 생성과 전 파를 모의하였다. 이를 통해 얻어진 주요한 결과를 다음과 같이 기술한다.

(1) 본 연구에서는 수중발파에 의한 수면파를 생성하기 위하 여 Le Méhauté and Wang(1996)의 경험식을 무반사 조파시스템 에 적용하는 조파방법을 제안하였다. 그리고 비교·검증을 통 해 수중발파에 따른 수면파의 생성 및 전파에 관한 수치파동수 조의 타당성 및 유효성을 확보하였다.

(2) 3차원 수치파동수조에서 토도 제거를 위한 수중발파 시나 리오별 수면파의 생성 및 전파를 모의하였다. 그 결과 단일/다 중발파의 각 조건에서 장약량이 많을수록, 발파수심이 깊을수 록 수면파동이 커졌다. 또한 발파수심이 깊을수록 $\eta_{\max }$ 가 크고, 파속이 증가하여 컨테이너 터미널 안벽에 도달하는 시간이 빨 라졌다.

(3) 수중발파지점이 각 컨테이너 터미널에 가까울수록 $\eta_{\max }$ 가 커지는 경향을 나타내었다. 특히, 남과 북의 컨테이너 터미널 안벽에서 중앙발파보다 남쪽 또는 북쪽발파 시에 $\eta_{\max }$ 가 증가 하였다. 그리고 서컨테이너 및 다목적 터미널에서는 증가 폭이 크지 않았다.

(4) 본 연구에서 검토한 토도 제거를 위한 수중발파 시나리오 에 따른 수면파는 가동 중인 부산신항만의 터미널에 미치는 영 향이 크지 않음을 확인하였다.

수중폭발에 의한 충격파, 압력강하에 의한 공동현상, 기포의 생성과 상승(팽창과 수축) 등의 복합적 상호작용 때문에 발생하 는 수면파동을 $\mathrm{CFD}$ 를 이용하여 직접 모의할 수 있지만, 광역에 서의 전파과정까지 추정하는 것은 사실상 불가능하다. 따라서 수중발파에 의한 수면파가 주변 해역에 미치는 영향을 분석에 는 본 연구처럼 장약량과 발파수심에 따른 수면파의 제원을 산 정하여 수면파를 생성하는 것이 더 효과적이다. 향후, 부산신항 
만에서 토도 제거를 위해 진행하고 있는 수중발파 시의 수면변 위 자료를 수집하여 수치파동수조에서 실제 조건을 적용한 모 의결과와 비교 · 검토를 수행할 예정이다.

\section{후기}

이 성과는 2018년도 정부(과학기술정보통신부)의 재원으로 한 국연구재단의 지원을 받아 수행된 연구임(No. NRF-2018R1C1B 6007461).

\section{References}

An, B.D., Lee, I.J., Heo, T.M., 2007. A Case Study of Underwater Blasting Using Emulsion Explosives. Explosives \& Blasting, 25(2), 71-78.

Brackbill, J.U., Kothe, D.B., Zemach, C., 1992. A Continuum Model for Modeling Surface Tension. Journal of Computational Physics, 100(2), 335-354.https://doi.org/10.1016/0021-9991(92) 90240-Y

Brorsen, M., Larsen, J., 1987. Source Generation of Nonlinear Gravity Waves with Boundary Integral Equation Method. Coastal Engineering, 11(2), 93-113. https://doi.org/10.1016/0378-3839 (87)90001-9

Carlson, T.J., Johnson, G.E., Woodley, C.M. Skalski, J.R., Seaburg, A., 2011. Compliance Monitoring of Underwater Blasting for Rock Removal at Warrior Point, Columbia River Channel Improvement Project, 2009/2010. Pacific Northwest National Laboratory Completion Report (PNNL-20388), Prepared for the U.S. Army Corps of Engineers. https://doi.org/10.2172/ 1023122

Choi, G., Jung, K., Jung, S.S., Kim, J.C., Lee, P.S., 2017. Underwater Explosion Experiments Using Pentolite. Explosives \& Blasting, 35(3), 21-30.

Choi, T.H., Kim, J.H., Song, H.L., Ko, C.S., 2015. Suggestion of Safety Level in Fish Farming by Impulsive Sound. Tunnel and Underground Space, 25(2), 125-132.https://doi.org/10.7474/ TUS.2015.25.2.125

Cole, R.H., 1948. Underwater Explosions. 1st Edition, Princeton University Press.

Costanzo, F.A., 2011. Underwater Explosion Phenomena and Shock Physics. Structural Dynamics, 3, 917-938. https://doi.org/ 10.1007/978-1-4419-9834-7 82

Dean, R.G., Dalrymple, R.A., 1991. Water Wave Mechanics for Engineers and Scientists. Advanced Series on Ocean Engineering, 2, World Scientific Publishing Company.

Germano, M., Piomelli, U., Moin, P., Cabot, W.H., 1991. A Dynamic Subgrid-Scale Eddy Viscosity Model. Physics of Fluids, 3(7), 1760-1765. https://doi.org/10.1063/1.857955

Govoni, J.J., West, M.A., Settle, L.R., Lynch, R.T., Greene, M.D., 2008. Effects of Underwater Explosions on Larval Fish: Implications for a Coastal Engineering Project. Journal of Coastal
Research, 24(2A), 228-233. https://doi.org/10.2112/05-0518.1

Hamashima, H., Shibuta, M., Nishimura, Y.. Itoh, S., 2010. Behavior of Bubble Pulse in Food Processing Using Underwater Shock Wave. The International Journal of Multiphysics, 4(2), 113-124. http://dx.doi.org/10.1260/1750-9548.4.2.113

Hinatsu, M., 1992. Numerical Simulation of Unsteady Viscous Nonlinear Waves using Moving Grid System Fitted on a Free Surface. Journal of the Kansai Society of Naval Architects, 217, 1-11. https://doi.org/10.14856/kansaiks.217.0_1

Hunter, K.S., Geers, T.L., 2002. Pressure and Velocity Fields Produced by an Underwater Explosion. The Journal of the Acoustical Society of America, 112(5), 2329-2329. https:// doi.org/10.1121/1.4779405

Hur, D.S., Lee, W.D., Bae, K.S., 2008. On Reasonable Boundary Condition for Inclined Seabed/Structure in Case of the Numerical Model with Quadrilateral Mesh System. Journal of the Korean Society of Civil Engineers, 28(5), 591-594.

Hur, D.S., Lee, W.D., 2011. On Generation Methods of Oblique Incidence Waves in Three-Dimensional Numerical Wave Tank with Non-Reflected System. Journal of Korean Society of Coastal and Ocean Engineers, 23(6), 401-406. https://doi.org/ 10.9765/KSCOE.2011.23.6.401

Hur, D.S., Lee, W.D., Cho, W.C., 2012. Three-Dimensional Flow Characteristics around Permeable Submerged Breakwaters with Open Inlet. Ocean Engineering, 44, 100-116. https://doi.org/ 10.1016/j.oceaneng.2012.01.029

Jeung, M.S., Park, J.H., Song, Y.S., 2004. A Case Study of Underwater Blasting. Explosives \& Blasting, 22(3), 57-64.

Keevin, T.M., Hempen, G.L., 1997. The Environmental Effects of Underwater Explosions With Methods to Mitigate Impacts. U.S. Army Corps of Engineers.

Kim, Y.K., Kim, S.K., 2018. A Case of Underwater Blasting Performance Using a Structural Underwater Charging System. Explosives \& Blasting, 36(2), 37-35.

Klaseboer, E., Hung, K.C., Wang, C., Wang, C.W., Khoo, B.C., Boyce P., Debono, S., Charlier, H., 2005. Experimental and Numerical Investigation of the Dynamics of an Underwater Explosion Bubble near a Resilient/Rigid Structure. Journal of Fluid Mechanics, 537, 387-413. https://doi.org/10.1017/S0022 112005005306

Le Méhauté, B., Wang, S., 1996. Water Waves Generated by Underwater Explosion. Advanced Series on Ocean Engineering, 10, World Scientific.

Lee, S., Kang, D.W., Park, H.B, 2001. A Study on the Effective Oscillation Characteristics of the Constructions of Blasting Operations in Seaside. Explosives \& Blasting, 19(1), 71-84.

Lee, W.D., Hur, D.S., 2014a. Development of 3-D Hydrodynamical Model for Understanding Numerical Analysis of Density Current due to Salinity and Temperature and its Verification. Journal of the Korean Society of Civil Engineers, 34(3), 859-871. https://doi.org/10.12652/Ksce.2014.34.3.0859 
Lee, W.D., Hur, D.S., 2014b. Development of a 3-D Coupled Hydro-Morphodynamic Model between Numerical Wave Tank and Morphodynamic Model under Wave-Current Interaction. Journal of the Korean Society of Civil Engineers, 34(5), 1463-1476. https://doi.org/10.12652/Ksce.2014.34.5.1463

Lee, W.D., Park, J,R., Jeon, H.S., Hur, D.S., 2016. A Study on Stable Generation of Tsunami in Hydraulic/Numerical Wave Tank. Journal of the Korean Society of Civil Engineers, 36(5), 805-817. https://doi.org/10.12652/Ksce.2016.36.5.0805

Lee, W.D., Park, J,R., Jeon, H.S., Hur, D.S., 2017. Effects of Tsunami Waveform on Energy Dissipation of Aquatic Vegetation. Journal of Ocean Engineering and Technology, 31(2), 121-129. https://doi.org/10.5574/KSOE.2017.31.2.121

Lee, W.D., Kim, J.O., Park, J,R., Hur, D.S., 2018. Effects of Tsunami Waveform on Overtopping and Inundation on a Vertical Seawall. Journal of Korea Water Resources Association, 51(8), 643-654.

Lilly, D.K., 1992. A Proposed Modification of the Germano Subgrid-Scale Closure Method. Physics of Fluids A, 4, 633-635. https://doi.org/10.1063/1.858280

Miller, S.T., Jasak, H., Boger, D.A., Paterson, E.G., Nedungadi, A., 2013. A Pressure-Based, Compressible, Two-Phase Flow Finite Volume Method for Underwater Explosions. Computers \& Fluids, 87, 132-143. https://doi.org/10.1016/j.compfluid. 2013.04.002

Ming, F.R., Zhang, A.M., Xue, Y.Z., Wang, S.P., 2016. Damage Characteristics of Ship Structures Subjected to Shockwaves of Underwater Contact Explosions. Ocean Engineering, 117, 359-382. https://doi.org/10.1016/j.oceaneng.2016.03.040

Ohyama, T., Nadaoka, K., 1991. Development of a Numerical Wave Tank for Analysis of Non-Linear and Irregular Wave Field.
Fluid Dynamics Research, 8, 231-251. https://doi.org/10.1016/ 0169-5983(91)90045-K

Park, Y.S., Park, S.J., Kang S.H., Jeon, Y.B., Gong, G.J., 2006. An Experimental Study on Ground Vibration Equations by Underwater Blasting at Construction Site. Transactions of the Korean Society for Noise and Vibration Engineering, 16(7), 777-783. https://doi.org/10.5050/KSNVN.2006.16.7.777

Saadatfar, S., Zahmatkesh, A., 2018. Evaluation of Underwater Blast on Concrete Gravity Dams Using Three-Dimensional FiniteElement Model. AUT Journal of Civil Engineering, 2(1), 69-78. https://doi.org/10.22060/AJCE.2018.13467.5416

Smagorinsky, J., 1963. General Circulation Experiments with the Primitive Equations. I. The Basic Experiment. Monthly Weather Review, 91(3), 99-164. https://doi.org/10.1175/1520-0493 (1963)091<0099:GCEWTP>2.3.CO;2

Wang, G., Zhang, S., Yu, M., Li, H., Kong, Y., 2014. Investigation of the Shock Wave Propagation Characteristics and Cavitation Effects of Underwater Explosion near Boundaries. Applied Ocean Research, 46, 40-53. https://doi.org/10.1016/j.apor.2014. 02.003

Jeung, M.S., Park, J.H., Song, Y.S., 2004. A Case Study of Underwater Blasting. Explosives \& Blasting, 22(3), 57-64.

Warren, W.D., 1996. The Response of Surface Ships to Underwater Explosion. Aeronautical and Maritime Research Laboratory, Melbourne, Austraila, DSTO-GD-109

Zhang, Z., Wang, L., Yao, X., Lang, J., 2017. Dynamics of an Underwater Explosion Bubble near a Rigid Wall: Effect of Slenderness Ratio, Installation, and Distance Parameter. Journal of Coastal Research, 33(4), 959-971. https://doi.org/10.2112/ JCOASTRES-D-16-00094.1 